\title{
nCoV-2019 infection induces neurological outcome and manifestation, linking its historical ancestor SARS-CoV \& MERS-CoV: A systematic review and meta-analysis
}

\author{
Ajay Prakash \\ PGIMER https://orcid.org/0000-0002-3487-8482 \\ Harvinder Singh \\ PGIMER \\ Phulen Sarma \\ PGIMER \\ Anusuya Bhattacharyya \\ $\mathrm{GMCH}$ \\ Deba Prasad Dhibar \\ PGIMER \\ Neeraj Balaini \\ PGIMER \\ Ritu Shree \\ PGIMER \\ Manoj Goyal \\ PGIMER \\ Manish Modi \\ PGIMER \\ BIKASH MEDHI ( $\nabla$ drbikashus@yahoo.com ) \\ https://orcid.org/0000-0002-4108-1180
}

Systematic Review

Keywords: COVID-19, nCoV-2019, SARS-CoV, MERS-CoV, CNS, PNS

Posted Date: June 17th, 2020

DOI: https://doi.org/10.21203/rs.3.rs-35790/v1

License: (c) (i) This work is licensed under a Creative Commons Attribution 4.0 International License. Read Full License 


\section{Abstract}

Importance: The first systematic review and meta-analysis to help clinician to identify early the sign and symptoms of neurological manifestation in COVID-19 positive patients which further help in early management of patients.

Objective: Present systematic review and meta-analysis aimed to discuss the prevalence of neurological involvement of the 2019-nCoV patients and assess the symptomatic trend of events as compared to the 2002 "SARS" and 2012 "MERS" pandemics.

Methods: The articles were systematically screened through several search engine and databases. The articles published or in preprint were included in the study till $15^{\text {th }}$ May 2020. The systematic review done as per the published literatures which included 31 cross sectional, observational studies and case reports which revealed neural sign and symptoms in SARS-COV-2 disease. For meta-analysis, we included 09 observational and cross sectional studies which included COVID-19 positive patients and assessed the predominance of various neurological sign and symptoms in COVID-19 patients relation to SARS-2002 and MERS-2012. Data were analyzed by using the "MedCalc Statistical Software version 19.2.6 and reported as pooled prevalence. Heterogeneity was investigated (standard $\mathrm{I}^{2}$ test).

Results: We have collected and screened about a total 2615 articles, finally we have included 31 articles for the systematic review and 09 for meta-analysis as per the inclusion/exclusion criteria. The analysis was made as per the prevalence rate of neurological symptoms during the COVID-19 positive patients. The cumulative neurological outcome of SARS-2002 and MERS-2012 was assessed to get the trends which is next tried to correlate the events with the current pandemic. During the analysis severity and outcome of neurological manifestations range from simple headache to vague non-focal complaints to severe neurologic impairment associated with seizure or meningitis.

Conclusion \& Relevance: Central and peripheral nervous system (CNS/PNS) manifestations were seen during the SARS2002, MERS-2012 and COVID-19. However, none of the publication found with the primary or secondary objective of finding the neurological manifestation in the COVID-19 patients and their mechanism which strengthen the importance to start more precise clinical trials.

\section{Key Points}

Question: Is COVID-19 infection induce neurological manifestation and concern about the nervous system involvement during the course of infection?

\section{Findings of Study}

Systematic review was done in total 31 studies and 09 studies $(n=11147)$ were included in the final meta-analysis. In our study, total of 09 studies (total 11147 patients) reported occurrence of CNS-PNS combined symptoms in COVID-19 positive patients, the proportion was $45.718 \%, 48.278 \%$ by random and fixed effect size model, respectively. As there was significant heterogeneity $95.53 \%$, (95\% Cl for $\mathrm{I}^{2} 93.45$ to 96.95), we used random effect model, whereas 9 studies (total 1114 patients) reported occurrence of CNS symptoms in COVID-19positive patients, the proportion was $26.166 \%$, $37.21 \%$ by random and fixed effect size model, respectively. As there was significant heterogeneity $95.19 \%$, ( $95 \% \mathrm{Cl}$ for $I^{2} 92.72$ to 96.82$)$, we used random effect model.

Meaning: Prevalence of combined CNS/PNS symptoms was found in about 46.8 to $48.311 \%$ of population which suggest that the concern of the neurological manifestations in COVID-19 patients. Therefore management require special attention to these patients. 
Interpretation: The prevalence of neurological sign and symptoms were taken as primary objective. Thereafter, the prevalence of each CNS/PNS symptoms was categorized and their prevalence studied. The selection of Bagheri et al 2020 may be discussed because they have done the cross sectional study with the neurological finding and correlated the data with prevalence of the COVID-19 positive patients. The proportion of patients presenting with neurological outcome and clinical/PCR positivity were done, however we had searched and followed all the possible findings available on online/web source, therefore, the data collection process may remain a limitation of work. Due to lack of data of SARS-CoV and MERS-CoV we have included the case reports, MERS and COVID-19 in CNS/PNS manifestations.

\section{Background}

Severe acute respiratory syndrome namely corona-virus 2 (2019-nCoV) pandemic has changed the understanding and viewpoint of viral infection and given a cause to think more critically in the management of viral infection. SARS-CoV-2 is said to be the version 7.0 of corona virus family and of $\beta$-type. COVID-19 may be asymptomatic or have mild to severe pneumonia like syndrome. ${ }^{1,2}$ Several research recommended that $2019-n C o V$ is one of the predominant virus that specifically target the human respiratory system. SARS, MERS and COVID-19 essentially exhibit as respiratory distress, which represented through slight respiratory problem to a serious respiratory distress syndrome (ARDS) and incidentally adjunct to gastrointestinal appearances ${ }^{2}$, cardiovascular and neurological conditions ${ }^{3}$. If we see the neurological capabilities is never been studies in any of the published literatures as a primary or secondary objectives. If we see the history of the corona virus family and its pandemic situations it came earlier in 2002 as SARS and MERS in 2012. But logically speaking the mortality rate worldwide indicate the prevailing high risk of the present 2019-nCoV compared to the other counterparts is more. ${ }^{5}$

The present systematic review and meta-analysis aimed to the evidence based its neurological manifestations and The common symptoms of nCoV-2019 infection start in 4-5 days with mild fever, mild to moderate cough, running nose and fatigue whereas other most common symptoms namely headache, hemoptysis, and dyspnea were reported in several studies. Moderate to severe cases of nCoV-2019 infection may worsen with the development of pneumonia, acute respiratory distress syndrome, acute cardiac problems, and multiorgan failure. ${ }^{5}$

Presently as on June 5, 2020 the complete Coronavirus Cases is 6,720,550, which precipitated 393,542 Deaths (5.85\%) and nearly $3,264,238$ recovered $(48.57 \%)^{6}$. This suggests that COVID-19 pandemic is one of major world public health issue which World Health Organization (WHO) formally think about as a world pandemic on 11 March 2020 and named as, COVID-19 outbreak ${ }^{7}$. Studies suggesting about the nCoV-2019 infections may have related neurological manifestations (e.g., febrile seizures, convulsions, change in mental status, and encephalitis) ${ }^{8,9}$. Very few reports have described the neurotropic and neuroinvasive abilities of corona viruses to humans, which suggest that nasal nCoV2019 infection, get access to CNS thru the olfactory bulb inflammation and demyelination ${ }^{10}$. Therefore, in the current systematic review, we will talk about the proof on the incidence of CNS involvement and neurological manifestations in population with COVID-19.

\section{Methods}

\section{Objectives}

Incidence of the neurological manifestation in 2019-nCoV and prevailing prevalence in the context of previous CoVSARS. Therefore $y$-the objective of the paper

1. Prevalence of neurological outcome in 2019-nCoV infected patients

2. Correlation of events in SARS, MERS and 2019-nCoV infection

Page $3 / 24$ 
3. Prevalence of CNS/PNS symptoms in all the corona pandemics

4. Network analysis of case reports of SARS, MERS and COVID-19

Search methods: The manuscript search is depending on the complete possible online sources. Out of total 1651 articles, finally we have included 32 articles for the systematic review and meta-analysis. The analysis were made in the two sections, one which is the current 2019-nCoV outbreak for the neurological/CNS manifestation and another is cumulative outcome of 2002 and 2012 SARS and MERS outbreak respectively.

Database search: Three independent reviewers AJ, HM and PS searched the Google Scholar, MEDLINE (Pubmed), EMBASE, OVID, Scopus, Science Direct and unpublished data were screened through Medrixv and BioRixv. The search strategy included both keyword and Medical Subject Headings (MeSH) terms. The keywords used were: "Neuro", "CNS", Central nervous System, "anxiety”, “depression”, "seizure”, "agitation”, "neurological”, "2019-nCov”, 2019 "novel corona virus", COVID-19, corona virus disease-2019, OR infarction for the corona virus -2 however, all previous studies for SARS2002 and MERS-2012 where searched with the key words "corona virus- SARS" OR SARS OR SARS--CoV AND "corona virus-MERS OR MERS OR MERS-CoV". During the screening process we have kept no language restrictions and for articles written in languages other than English, google translate was used to obtain relevant information and extract data if possible, otherwise it was excluded from the analysis. In cases in which the translation cannot work out we have collected data only from the abstract (if it is in English). We retrieved the full text article of the potentially eligible study after screening the title, summary/ abstract and type of study as described by search result which met the eligibility criteria for current systematic review and meta-analysis. Databases were systematically searched thoroughly and duplicates were independently screened by authors (DP, NB, AB and HM). In the next phase articles were selected as per the titles/abstracts published and have the relevance as neurological outcome in COVID-19. For relevant articles, the full texts was obtained and evaluated as per neurological sign and symptoms in nCoV-19 infected patients. BM, MM, MG and AP were consulted for any discrepancy or confusion. Four authors (HS, DP, RS and NB) have extracted data independently by using pre-tested Cochrane data extraction form. After independently verifying by BM, MM, MG and AP, the data was entered into MedCalc software and analyzed.

Selection criteria: The Preferred Reporting Items for Systematic Reviews and Meta-Analyses (PRISMA) and Metaanalysis of Observational Studies in Epidemiology (MOOSE) were followed to analyze and report systematic review and meta-analysis (Figure. 1). The registration of the review protocol was not previously done. The thorough search engine were used to collect all possible studies through Google scholar, MEDLINE (Pub Med), EMBASE, OVID, Cochrane Central Library, CNKI, Medrixv and BioRixv and Scopus till May 15, 2020.

Statistical analysis: To analyze the differences in neurological impact, levels of anosmia/hyposmia, dyspnea, headache, headache and loss of consciousness were calculated according to the number of respondents per response to the number of total patients as categorical variables. Differences categorical variables were analyzed for proportion analysis by chi-squared test. We used network analysis to correlate with the different pandemics namely SARS-2002, MERS-2012 and COVID-19. Data were analyzed by using the "MedCalc Statistical Software version 19.2.6 (MedCalc Software bv, Ostend, Belgium; https://www.medcalc.org; 2020)" and reported as pooled prevalence using a fixed and random effect model. Heterogeneity was investigated (standard $\chi 2$ test) and represented as $1^{2}$ for the degree of inconsistency. Analyzed report showed both fixed effect and random effect model as necessary as an indication of the variability in the studies. The significant level set at $\mathrm{p}<0.05$ and prevalence range were represented as $95 \% \mathrm{Cl}$. Publication bias in the selected study was evaluated by plotting the funnel plot and done the analysis accordingly.

\section{Results}


Inclusion/exclusion of studies: Total 2615 articles were found in databases search and after duplicate, title and summary screening articles reduced to 1651, thereafter, a total of 1459 articles were excluded. Full-text screening of the remaining 1156 articles was done. Among these studies, after full-text screening, a total of 31 articles were included in the final review. (Figure 1)

Data collection and analysis: A total of 1651 articles were found after preliminary screening of the databases. After title and abstract screening, a total of 495 articles were excluded. Full-text screening of the remaining 1156 articles was done. Among these studies, after full-text screening, a total of 247 articles were included in the final review. The PRISMA flowchart of the study is shown in Figure 1, 215 articles were excluded after full-text screen (Not related to neurological manifestation=32, Reports (incomplete data) $=78$, In silico / in vitro study=30, Management of SARS, MERS or COVID$19=55$, Incomplete epidemiological study=20). Details of studies with neurological manifestation in SARS-2002, MERS2012 and COVID-19 summarized in Table 1,2 \& 3.

\section{Prevalence of nervous system complication/manifestations in COVID-19 positive patients}

\section{Overall prevalence of central and peripheral nervous system (CNS/PNS) symptoms}

A total of 09 studies (total 11147 patients) reported occurrence of CNS-PNS combined symptoms in COVID-19 positive patients, the proportion was $48.278 \%, 45.718 \%$ by fixed and random effect size model, respectively. As there was significant heterogeneity $96.00 \%$, (95\% Cl for $\mathrm{I}^{2} 94.08$ to 97.29$)$, we used random effect model. The forest plot is showed in Figure 2a. No significant publication bias was seen (Figure 2b).

\section{Overall prevalence of nervous system symptoms (CNS)}

A total of 08 studies (total 1078 patients) reported occurrence of CNS symptoms in COVID-19 positive patients, the proportion was $25.184 \% \& 34.890 \%$ by fixed and random effect size model, respectively. As there was significant heterogeneity $95.32 \%$, (95\% Cl for $\mathrm{I}^{2} 92.75$ to 96.98$)(\mathrm{P}<0.0001)$, we used random effect model. The forest plot is showed in Figure 3a. Publication bias was seen, may be due to less number of publication. (Figure $3 b$ ).

\section{Overall prevalence of peripheral nervous system (PNS) symptoms}

A total of 08 studies (total 11009 patients) reported occurrence of PNS symptoms in COVID-19 positive patients, the proportion $41.366 \%$ \& $48.386 \%$ by random and fixed effect size model, respectively. As there was significant heterogeneity $98.82 \%\left(95 \% \mathrm{Cl}\right.$ for $\mathrm{I}^{2} 98.43$ to 99.11$)(\mathrm{P}<0.0001)$, we used random effect model. The forest plot is showed in Figure 4a. No significant publication bias was seen (Figure 4b).

\section{Prevalence of ANSOMIAVHPOSMIA as symptoms}

A total of 3 studies (total 10769 patients) reported occurrence of ANSOMIA/HYPOSMIA symptoms in COVID-19 positive patients, the proportion $48.547 \%, 37.270 \%$ by random and fixed effect size model, respectively. As there was significant heterogeneity $99.47 \%$ (95\% Cl for $\mathrm{I}^{2} 99.26$ to 99.61 ), we used random effect model. The forest plot is showed in Figure 5a. Publication bias was seen, may be due to very less number of publication. (Figure $5 b$ ).

\section{Overall prevalence of nervous system symptoms (Myalgia)}

A total of 2 studies (total 77 patients) reported occurrence of Myalgia symptoms in COVID-19 positive patients, the proportion $21.279 \%, 19.994 \%$ by random and fixed effect size model, respectively. As there was significant heterogeneity $95.40 \%$ (95\% Cl for $\mathrm{I}^{2} 86.48$ to 98.44 ), we used random effect model. The forest plot is showed in Figure 6a. No significant publication bias was seen (Figure 6b). 


\section{Overall prevalence of nervous system symptoms (Fatigue)}

A total of 2 studies (total 135 patients) reported occurrence of Fatigue symptoms in COVID-19 positive patients, the proportion $24.674 \%$ \& $30.810 \%$ by fixed and random effect size model, respectively. As there was significant heterogeneity $91.33 \%$ (95\% Cl for $\mathrm{I}^{2} 69.43$ to 97.54$)(\mathrm{P}=0.0007)$, we used random effect model. The forest plot is showed in Figure 7a. No significant publication bias was seen (Figure 7b).

\section{Overall prevalence of nervous system symptoms (Dyspnea)}

A total of 5 studies (total 731 patients) reported occurrence of Dyspnea symptoms in COVID-19 positive patients, the proportion $15.419 \% \& 26.131 \%$ by fixed and random effect size model, respectively. As there was significant heterogeneity $95.48 \%\left(95 \% \mathrm{Cl}\right.$ for $\mathrm{I}^{2} 92.01$ to 97.44$)(\mathrm{P}<0.0001)$, we used random effect model. The forest plot is showed in Figure 8a. No significant publication bias was seen (Figure 8b).

\section{Overall prevalence of nervous system symptoms (Headache)}

A total of 3 studies (total 629 patients) reported occurrence of Headache symptoms in COVID-19 positive patients, the proportion $10.263 \%, 9.727 \%$ by random and fixed effect size model, respectively. As there was not significant heterogeneity $52.06 \%\left(95 \% \mathrm{Cl}\right.$ for $\mathrm{I}^{2} 0.00$ to 86.21$)$, we used random effect model. The forest plot is showed in Figure 9a. No significant publication bias was seen (Figure 9b).

\section{Overall prevalence of nervous system symptoms (Impaired Consciousness)}

A total of 2 studies (total 629 patients) reported occurrence of Impaired Consciousness symptoms in COVID-19 positive patients, the proportion $9.471 \%, 13.580 \%$ by random and fixed effect size model, respectively. As there was significant heterogeneity $83.49 \%$ (95\% Cl for $\mathrm{I}^{2} 31.48$ to 96.02 ), we used random and fixes effect model. The forest plot is showed in Figure 10a. No significant publication bias was seen (Figure 10b).

\section{Network analysis of neurological manifestations}

The network analysis of case reports $(n=103)$ showed the neuronal manifestation of COVID-19 and other CoV infection is widely correlated with each other, whereas, analysis showed that the COVID-19 pandemic have more degree of neuronal manifestation as compared with other SARS and MERS pandemics in 2002 and 2012 respectively. (Figure 11) The number of study reported in previous SARS-CoV and MERS-CoV infection were minimal as compared to the COVID19 reporting. The individual neuronal manifestation of CNS or PNS nature ranges from simple headache to the Seizure or GBS and even Lau KK et al, $2004^{33}$ reported Myalgia and Al-Hameed FM et al, 2017 reported of GTC (Seizure) ${ }^{38}$ by Intracerebral hemorrhage. Kim JE et al, $2017^{39}$ reported Guillain-Barré syndrome (GBS), confusion and seizure of several patients. However, in the recent nCoV-2019 pandemic it was seen more neurological involvement i.e. Duong L et al, $2020^{19}$ and Moriguchi T, et al, $2020^{22}$ have reported about the meningoencephalitis, Scheidl et al, $2020^{24}$, Sedaghat Z et al, $2020^{25}$, Toscano G, et al $2020^{27}$, Virani A et al, $2020^{28}$ and Zhao H et al, $2020^{29}$ have reported of Guillain-Barré syndrome. (Table 2 \& 3 ; Figure 12)

Gutiérrez-Ortiz C et al, $2020^{46}$ reported the single event of Miller Fisher Syndrome and polyneuritis cranialis as neurological manifestations, proposed the absence of immune response during COVID-19.

\section{Discussion}


The present systematic review and meta-analysis revealed that the pattern of neurological manifestation of nCoV-2019 is related to the previous two pandemics i.e. SARS-2002 and MERS-2012. The main clinical manifestations of SARS and MERS were fever, chills, dry cough, and difficulty breathing which is related to the 2019-nCoV symptoms as well. In moderate to severe cases, respiratory failure associated with multiple organ involvement may occur ${ }^{33}$. In addition, these patients found to be neurological manifestations such as encephalitis, polyneuropathy, and aortic ischemic stroke ${ }^{38}$. An autopsy sample revealed overall deteriorating findings namely infiltration of monocytes and lymphocytes in the vessel wall, ischemic changes of neurons, demyelization of nerve fibers to the cerebral edema and meningeal vasodilation in patients.

Present systematic review and metaanalysis aimed to access the neurological manifestation of nCoV-2019 infection were further classified as central nervous system (CNS) symptoms namely dizziness, headache, impaired consciousness, acute cerebrovascular disease, ataxia, and epilepsy and peripheral nervous system (PNS) symptoms like hypoplasia, hyposmia, neuralgia, and hypogeusia were studied ${ }^{16}$.

In Study by Hung EC et al, $2003^{31}$ showed SARS positive evidenced in CSF sample of SARS-CoV and genome sequences of SARS in brain sample (Guetal., 2005; Zhangetal.,2003). MERS outbreak in 2012-13 also reported delirium, neuropathy and acute cerebrovascular disease ${ }^{35,37}$ where as Saad et al, $2014^{21}$ reported confusion and seizures in 18 and 6 of the participants, respectively out of 70 MERS patients. Therefore, published literature showed the indication of neurotropism by the CoV- family. Recent study by Moriguchi, et al. 202022, showed patients with SARS-CoV-2 suffered from meningitis / encephalitis which were confirmed by RT-PCR detection in cerebrospinal fluid. The exact reason is unclear, but the few described in the literature are, development of focal meningitis/encephalitis affecting the rhino- or gustatory-cortex representations or appropriate sub-cortical ascending/descending tracts in the CoV positive patients is one of the reason which may be easily detect viral-RNA in the cerebrospinal fluid (CSF) of infected patients ${ }^{16,22}$. In our network study meningitis/encephalitis, seizure and confusion were well connected to the MERS and COVID-19.

The symptoms of PNS appeared due to involvement of peripheral nerves, including the cranial nerves which further associate to cranial nerves I, VII, IX, and X by SARS-CoV $2^{47}$. Our study study reported common neurological sign and symptoms were dyspnea $(15.419 \% \& 26.131 \%)$, fatigue, myalgia $(19.994 \%-21.279)$, loss of counciousness $(9.471 \%$ to $13.580 \%$ ) and agnosia. However, few case reports have reported even more severe neurological manifestation like seizure, GBS or meningitis/encephalopathy. (Figure 11,12) However, none of the studies observed the viral neurotropism but few author have reported that the patients with neurological manifestation have the positive CSF of COVID-1939. Therefore, it is very early to explain the event whether neurological dysfunction is due to direct viral injury or systemic disease.

The other school of thought showed that the neurotropism of CoV family occur mainly through two pathways, i.e. the hematogenous and neuronal retrograde courses of CNS infection through respiratory infection. An animal study showed MERS-CoV tissue pantropism occur after the viral entry into blood stream through endothelial infection in the choroid plexus $^{23,40}$.

High mortality and fast spread of the CoV-family namely SARS, MERS and 2019-nCoV infection due to the high fusion of these virus and rapid replication involved angiotensin-converting enzyme 2 (ACE2) receptor which is present throughout the vital organs ${ }^{17}$. Therefore, the presence of ACE 2 receptor in brain is an important factor and link to study the neurological manifestation and management in 2019-nCoV infection. Patel AB, $2020^{41}$ described that there is evidence for a major involvement of excessive brain ACE/ Ang II/ AT-1R axis in increased activation of oxidative stress, apoptosis and neuroinflammation causing neurodegeneration and other brain disorders. At last the probable chance of neurological manifestation may be due to the cytokines overload and reduced immunity. Immunoinflamation plays an

Page $7 / 24$ 
important role in viral infection and which leads to the systemic inflammatory response syndrome (SIRS) ${ }^{42}$. In vitro study suggested that primary glial cells released a large number of inflammatory cytokines namely IL-6, IL-12, IL-15, and TNF-a after being infected with $\mathrm{CoV}^{43}$. Further, study suggests that virus-induced SIRS or SIRS-like immune disorders may cause mortality due to involvement of macrophages, microglia, and astrocytes in the CNS ${ }^{44}$.

\section{Abbreviations}

SARS: Severe Acute Respiratory Syndrome; MERS: Middle East respiratory syndrome; ARDS: Serious respiratory distress syndrome; COVID-19: Coronavirus Disease 19; nCoV-2019: Corona virus 2019; SIRS: Systemic inflammatory response syndrome; RT-PCR: Real time polymerase chain reaction

\section{Declarations}

\section{Authors Contributions}

After the conception of idea of study AP and BM have designed the study with DP, MM and MG. Systematic databases were searched thoroughly by authors HM, DP, PS, NB, PS and AB. Articles were selected as per the titles/abstracts published and have the relevance as neurological outcome in COVID-19. For relevant articles, the full texts was obtained and evaluated as per neurological sign and symptoms in nCoV-19 infected patients. BM, MM, MG and AP were consulted for any discrepancy. Four authors (HS, DP, RS and NB) were extracted the data independently by using pretested Cochrane data extraction form. After independently verifying by BM, MM, MG and AP, the data was entered into MedCalc software for review and interpretation.

Declarations of interest: The authors have declared that there is no conflict of interest.

Disclaimer: All statements in this systematic review, including its findings and conclusions, are solely those of the author's analysis and viewpoints.

Funding: The study is self funded and not received any funding from any sources.

\section{References}

1. Prajapat M, Sarma P, Shekhar N, et al. Drug targets for corona virus: A systematic review. Indian J Pharmacol. 2020;52(1):56-65. doi:10.4103/ijp.IJP_115_20.

2. Huang C, Wang Y, Li X et.al.Clinical Features of Patients Infected With 2019 Novel Coronavirus in Wuhan, China. Lancet. 2020 Feb 15;395(10223):497-506. doi: 10.1016/S0140-6736(20)30183-5.

3. Lauer SA, Grantz KH, Bi Q et. al. The Incubation Period of Coronavirus Disease 2019 (COVID-19) From Publicly Reported Confirmed Cases: Estimation and Application. Ann Intern Med. 2020 May 5;172(9):577-582. doi: 10.7326/M20-0504.

4. Ng Kee Kwong KC, Mehta PR, Shukla G, Mehta AR. COVID-19, SARS and MERS: A neurological perspective [published online ahead of print, 2020 May 5]. J Clin Neurosci. 2020;S0967-5868(20)31185-1.

doi:10.1016/j.jocn.2020.04.124.

5. COVID-19 CORONAVIRUS PANDEMIC. https://www.worldometers.info/coronavirus/. Assessed on May 26, 2020 at $1: 36 \mathrm{AM}$.

6. Coronavirus disease (COVID-19) Pandemic. 2020. https://www.who.int/emergencies/diseases/novel-coronavirus2019/events-as-they-happen Assessed on May 26, 2020. 
7. Li YC, Bai WZ, Hashikawa T. The neuroinvasive potential of SARS-CoV2 may play a role in the respiratory failure of COVID-19 patients [published online ahead of print, 2020 Feb 27]. J Med Virol. 2020;10.1002/jmv.25728. doi:10.1002/jmv.25728.

8. Karimi N, Sharifi Razavi A, Rouhani N. Frequent Convulsive Seizures in an Adult Patient with COVID-19: A Case Report, Iran Red Crescent Med J. 2020 ; 22(3):e102828.

9. Koyuncu OO, Hogue IB, Enquist LW. Virus infections in the nervous system. Cell Host Microbe. 2013;13(4):379-393. doi:10.1016/j.chom.2013.03.010

10. Bagheri SH, Asghari AM, Farhadi M, Shamshiri AR, Kabir A, Kamrava SK, Jalessi M, Mohebbi A, Alizadeh R, Honarmand AA, Ghalehbaghi B. Coincidence of COVID-19 epidemic and olfactory dysfunction outbreak. Medrxiv. 2020 Jan 1.

11. Chen N, Zhou M, Dong X et al. Epidemiological and clinical characteristics of 99 cases of 2019 novel coronavirus pneumonia in Wuhan, China: a descriptive study. Lancet 2020; 395: 507-13. doi.org/10.1016/ S01406736(20)30211-7.

12. Helms J, Kremer S, Merdji H, et al. Neurologic Features in Severe SARS-CoV-2 Infection. N Engl J Med. 2020;382(23):2268-2270. doi:10.1056/NEJMc2008597.

13. Huang C, Wang Y, Li X et al. Clinical features of patients infected with 2019 novel coronavirus in Wuhan, China. Lancet 2020; 395: 497-506. doi.org/10.1016/S0140-6736(20)30183-5.

14. Huang Y, Yang R, Xu Y et al. Clinical characteristics of 36 non-survivors with COVID-19 in Wuhan, China. medRxiv 2020.02.27.20029009; doi: https://doi.org/10.1101/2020.02.27.20029009.

15. Lechien JR, Chiesa-Estomba CM, De Siati DR, et al. Olfactory and gustatory dysfunctions as a clinical presentation of mild-to-moderate forms of the coronavirus disease (COVID-19): a multicenter European study [published online ahead of print, 2020 Apr 6]. Eur Arch Otorhinolaryngol. 2020;1-11. doi:10.1007/s00405-020-05965-1.

16. Mao L, Wang M, Chen S, He Q, Chang J, Hong C, Zhou Y, Wang D, Miao X, Hu Y, Li Y. Neurological manifestations of hospitalized patients with COVID-19 in Wuhan, China: a retrospective case series study. JAMA Neurol. 2020 Apr 10;e201127. doi: 10.1001/jamaneurol.2020.1127.

17. Wang D, Hu B, Hu C, Zhu F, Liu X, et al. Clinical Characteristics of 138 Hospitalized Patients with 2019 Novel Coronavirus-Infected Pneumonia in Wuhan, China. JAMA 2020. https://doi.org/10.1001/jama.2020.1585.

18. Wang Z, Yang B, Li Q et al. Clinical Features of 69 Cases with Coronavirus Disease 2019 in Wuhan, China. Clin Infect Dis. 2020 Mar 16: ciaa272. Published online 2020 Mar 16. doi: 10.1093/cid/ciaa272.

19. Duonga L, Xub P, Liua A. Meningoencephalitis without respiratory failure in a young female patient with COVID-19 infection in Downtown Los Angeles, early April 2020. Brain Behav Immun. 2020 Apr 17; S0889-1591(20)30509-2. doi: 10.1016/j.bbi.2020.04.024.

20. Al-Hameed FM. Spontaneous intracranial hemorrhage in a patient with Middle East respiratory syndrome corona virus Fahad M. Saudi Med J 2017; Vol. 38 (2): 196-200 doi: 10.15537/smj.2017.2.16255.

21. Saad M, Omrani AS, Baig K, et al. Clinical aspects and outcomes of 70 patients with Middle East respiratory syndrome coronavirus infection: a single-center experience in Saudi Arabia. Int J Infect Dis. 2014;29:301-306. doi:10.1016/j.ijid.2014.09.003.

22. Moriguchi T, Harii N, Goto J, Harada D, Sugawara H, Takamino J, Ueno M, Sakata H, Kondo K, Myose N, Nakao A. A first case of meningitis/encephalitis associated with SARS-Coronavirus-2. International Journal of Infectious Diseases. 2020 Apr 3.

23. Paniz-Mondolfi A, Bryce C, Grimes Z, et al. Central Nervous System Involvement by Severe Acute Respiratory Syndrome Coronavirus -2 (SARS-CoV-2) [published online ahead of print, 2020 Apr 21]. J Med Virol. 2020;10.1002/jmv.25915. doi:10.1002/jmv.25915. 
24. Scheidl E, Canseco DD, Hadji-Naumov A, Bereznai B. Guillain-Barré syndrome during SARS-CoV-2 pandemic: A case report and review of recent literature [published online ahead of print, 2020 May 10]. J Peripher Nerv Syst. 2020;10.1111/jns.12382. doi:10.1111/jns.12382.

25. Sedaghat Z, Karimi N. Guillain Barre syndrome associated with COVID-19 infection: A case report [published online ahead of print, 2020 Apr 15]. J Clin Neurosci. 2020;76:233-235. doi:10.1016/j.jocn.2020.04.062.

26. Somani S, Pati S, Gaston T, Chitlangia A, Agnihotri S. De Novo Status Epilepticus in patients with COVID-19 [published online ahead of print, 2020 May 14]. Ann Clin Transl Neurol. 2020;10.1002/acn3.51071. doi:10.1002/acn3.51071.

27. Toscano G, Palmerini F, Ravaglia S, et al. Guillain-Barré Syndrome Associated with SARS-CoV-2 [published online ahead of print, 2020 Apr 17]. N Engl J Med. 2020; NEJMc2009191. doi:10.1056/NEJMc2009191.

28. Virani A, Rabold E, Hanson T, et al. Guillain-Barré Syndrome associated with SARS-CoV-2 infection [published online ahead of print, 2020 Apr 18]. ID Cases. 2020; 20:e00771. doi:10.1016/j.idcr.2020.e00771.

29. Zhao H, Shen D, Zhou H, Liu J, Chen S. Guillain-Barré syndrome associated with SARS-CoV-2 infection: causality or coincidence?. Lancet Neurol. 2020;19(5):383-384. doi:10.1016/S1474-4422(20)30109-5.

30. Chao CC, Tsai LK, Chiou YH, et al. Peripheral nerve disease in SARS:: report of a case. Neurology. 2003;61(12):18201821. doi:10.1212/01.wnl.0000099171.26943.d0.

31. Hung EC, Chim SS, Chan PK, et al. Detection of SARS coronavirus RNA in the cerebrospinal fluid of a patient with severe acute respiratory syndrome. Clin Chem. 2003;49(12):2108-2109. doi:10.1373/clinchem.2003.025437.

32. Hwang CS. Olfactory neuropathy in severe acute respiratory syndrome: report of A case. Acta Neurol Taiwan. 2006;15(1):26-28.

33. Lau KK, Yu WC, Chu CM, Lau ST, Sheng B, Yuen KY. Possible central nervous system infection by SARS coronavirus. Emerg Infect Dis. 2004; 10(2):342-344. doi:10.3201/eid1002.030638.

34. Umapathi T, Kor AC, Venketasubramanian N, et al. Large artery ischaemic stroke in severe acute respiratory syndrome (SARS). J Neurol. 2004; 251(10):1227-1231. doi:10.1007/s00415-004-0519-8.

35. Algahtani H, Subahi A, Shirah B. Neurological Complications of Middle East Respiratory Syndrome Coronavirus: A Report of Two Cases and Review of the Literature. Case Rep Neurol Med. 2016; 2016:3502683. doi:10.1155/2016/3502683.

36. Arabi YM, Harthi A, Hussein J, et al. Severe neurologic syndrome associated with Middle East respiratory syndrome corona virus (MERS-CoV). Infection. 2015; 43(4):495-501. doi:10.1007/s15010-015-0720-y.

37. Kim JE, Heo JH, Kim HO, et al. Neurological Complications during Treatment of Middle East Respiratory Syndrome. J Clin Neurol. 2017;13(3):227-233. doi:10.3988/jcn.2017.13.3.227.

38. Tsai LK, Hsieh ST, Chao CC, et al. Neuromuscular disorders in severe acute respiratory syndrome. Arch Neurol. 2004;61(11):1669-1673. doi:10.1001/archneur.61.11.1669.

39. Conde Cardona G, Quintana Pájaro LD, Quintero Marzola ID, Ramos Villegas Y, Moscote Salazar LR. Neurotropism of SARS-CoV 2: Mechanisms and manifestations. J Neurol Sci. 2020;412:116824. doi:10.1016/j.jns.2020.116824.

40. Li YC, Bai WZ, Hashikawa T. The neuroinvasive potential of SARS-CoV2 may play a role in the respiratory failure of COVID-19 patients [published online ahead of print, 2020 Feb 27]. J Med Virol. 2020;10.1002/jmv.25728. doi:10.1002/jmv.25728.

41. Patel VB, Zhong JC, Grant MB, Oudit GY. Role of the ACE2/Angiotensin 1-7 axis of the renin-angiotensin system in heart failure. Circ Res. 2016;118:1313-1326. doi: 10.1161/CIRCRESAHA.116.307708.

42. Mehta P, McAuley DF, Brown M, et al. COVID-19: consider cytokine storm syndromes and immunosuppression. Lancet. 2020;395(10229):1033-1034. doi:10.1016/S0140-6736(20)30628-0

Page $10 / 24$ 
43. Bohmwald K, Gálvez NMS, Ríos M, Kalergis AM. Neurologic Alterations Due to Respiratory Virus Infections. Front Cell Neurosci. 2018;12:386. Published 2018 Oct 26. doi:10.3389/fncel.2018.00386.

44. Yin CH, Wang C, Tang Z, Wen Y, Zhang SW, Wang BE. Zhongguo Wei Zhong Bing Ji Jiu Yi Xue. 2004;16(11):646650.

45. Sarma P, Prajapat M, Avti P, Kaur H, Kumar S, Medhi B. Therapeutic options for the treatment of 2019-novel coronavirus: An evidence-based approach. Indian J Pharmacol. 2020;52(1):1-5. doi:10.4103/ijp.IJP_119_20.

46. Gutiérrez-Ortiz C, Antonio Méndez, Sara Rodrigo-Rey, Eduardo San Pedro-Murillo, Laura Bermejo-Guerrero, Ricardo Gordo-Mañas, Fernando de Aragón-Gómez, Julián Benito-León. Miller Fisher Syndrome and polyneuritis cranialis in COVID-19 Neurology Apr 2020, 10.1212/WNL.0000000000009619; DOI: 10.1212/WNL.0000000000009619.I

47. Finsterer J, Stollberger C. Causes of hypogeusia/hyposmia in SARS-CoV2 infected patients [published online ahead of print, 2020 Apr 20]. J Med Virol. 2020;10.1002/jmv.25903. doi:10.1002/jmv.25903.

\section{Tables}

Table: 1; Published observational/cross sectional studies which reported the neurological manifestation to the COVID-19 positive patients 


\begin{tabular}{|c|c|c|c|c|c|c|c|c|}
\hline $\begin{array}{l}\text { Author, } \\
\text { year }\end{array}$ & $\begin{array}{l}\text { Sample } \\
\text { Size } \\
\text { (SS) }\end{array}$ & $\begin{array}{l}\text { Type of Study } \\
\text { (ST) }\end{array}$ & $\begin{array}{l}\text { Patient } \\
\text { Population }\end{array}$ & Treatment & Neurological condition (NC) & $\begin{array}{l}\text { 2019-nCoV } \\
\text { Presence and } \\
\text { diagnosis }\end{array}$ & $\begin{array}{l}\text { Type of NS } \\
\text { involvement } \\
\text { (CNS/PNS) } \\
\text { (NSI) }\end{array}$ & Remarks \\
\hline $\begin{array}{l}\text { Bagheri et } \\
\text { al } 2020^{10}\end{array}$ & 10069 & $\begin{array}{l}\text { Cross- } \\
\text { sectional } \\
\text { study }\end{array}$ & COVID-19 & NA & $\begin{array}{l}\text { Anosmia/Hyposmia } \\
(48.23 \%)\end{array}$ & NA & PNS & $\begin{array}{l}\text { Olfactory dysfunction } \\
\text { happened in Iran during } \\
\text { the COVID-19 epidemic, } \\
\text { that correlates with the } \\
\text { number of } \\
\text { patients infected with } \\
\text { COVID-19 across the } \\
\text { country. }\end{array}$ \\
\hline $\begin{array}{l}\text { Chen N et } \\
a l, 2020^{11}\end{array}$ & 99 & Observational & $\begin{array}{l}\text { COVID-19 } \\
\text { positive }\end{array}$ & $\begin{array}{l}\text { Oseltamivir, Ganciclovir, } \\
\text { Lopinavir Ritonavir, } \\
\text { Cephalosporins, } \\
\text { Quinolones, Carbapenems, } \\
\text { tigecycline }\end{array}$ & $\begin{array}{l}\text { Dyspnea (21 [58.33\%] } \\
\text { patients), Fatigue (17 } \\
{[47.22 \%] \text { patient). }}\end{array}$ & RT-PCR & CNS \& PNS & $\begin{array}{l}\text { 2019-nCoV was of } \\
\text { clustering onset, is } \\
\text { more likely to infect } \\
\text { older men with co- } \\
\text { morbidities. }\end{array}$ \\
\hline $\begin{array}{l}\text { Helms J, } \\
2020^{12}\end{array}$ & 64 & Observational & $\begin{array}{l}\text { COVID-19 } \\
\text { positive }\end{array}$ & $\begin{array}{l}\text { Midazolam } \\
\text { Propofol } \\
\text { Sufentanil }\end{array}$ & $\begin{array}{l}\text { Neurological sign }(49 / 58) \\
\text { Agitation }(40 / 58) \\
\text { Confusion }(26 / 58) \text {, enhanced } \\
\text { tendon reflexes, ankle clonus, } \\
\text { and bilateral extensor plantar } \\
\text { reflexes }(39 / 58), \\
\text { inattention, disorientation, or } \\
\text { poorly organized movements } \\
(15 / 45) \\
\text { Cerebral ischemic stroke } \\
\text { (3/13) } \\
\text { Encephalopathy (1/8) }\end{array}$ & $\begin{array}{l}\text { RT-PCR } \\
\text { CSF }\end{array}$ & CNS \& PNS & $\begin{array}{l}\text { At the initial stage } \\
\text { author have unable to } \\
\text { decide the features of } \\
\text { critical } \\
\text { illness-related } \\
\text { encephalopathy, } \\
\text { cytokines, or the effect } \\
\text { or withdrawal of } \\
\text { medication, and which } \\
\text { features were specific to } \\
\text { SARS-CoV-2 infection. }\end{array}$ \\
\hline $\begin{array}{l}\text { Huang C } \\
\text { et al, } \\
2020^{13}\end{array}$ & 41 & & $\begin{array}{l}\text { COVID-19 } \\
\text { positive }\end{array}$ & $\begin{array}{l}\text { Remdesivir } \\
\text { Lopinavir and Ritonavir } \\
\text { Corticosteroid }\end{array}$ & $\begin{array}{l}\text { Headache }(3 / 38) \text {, } \\
\text { Dyspnea }(22 / 40), \\
\text { Myalgia }(18 / 41)\end{array}$ & RT-PCR & CNS \& PNS & $\begin{array}{l}\text { The neurological sign } \\
\text { and symptoms appear } \\
\text { in around } 3 \% \text { to } 44 \% \text { of } \\
\text { patients. }\end{array}$ \\
\hline $\begin{array}{l}\text { Huang Y } \\
\text { et al, } \\
2020^{14}\end{array}$ & 36 & Observational & $\begin{array}{l}\text { COVID-19 } \\
\text { positive }\end{array}$ & $\begin{array}{l}\text { Oseltamivir, } \\
\text { Ganciclovir, } \\
\text { Ribavirin Orumifenovir } \\
\text { hydrochloride(35/36) }\end{array}$ & $\begin{array}{l}\text { Shortness of breath }(21 / 36) \text {, } \\
\text { Dyspnea }(14 / 36) \\
\text { Disturbance of consciousness } \\
(8 / 36), \\
\text { Fatigue }(17 / 36) \\
\text { Myalgia }(1 / 36)\end{array}$ & RT-PCR & CNS \& PNS & $\begin{array}{l}\text { Reported most non- } \\
\text { survivors are older men } \\
\text { with comorbidities } \\
\text { conditions especially } \\
\text { cardiovascular diseases } \\
\text { and COPD. }\end{array}$ \\
\hline $\begin{array}{l}\text { Lechien } \\
\text { JR et al, } \\
2020^{15}\end{array}$ & 417 & Observational & $\begin{array}{l}\text { COVID-19 } \\
\text { positive }\end{array}$ & NA & $\begin{array}{l}\text { Anosmic }(284 / 417) \\
\text { Hyposmic }(73 / 417) \\
\text { Dyspnea }(54 / 417)\end{array}$ & $\begin{array}{l}\text { Nasopharyngeal } \\
\text { swab test (RT- } \\
\text { PCR }\end{array}$ & CNS & $\begin{array}{l}\text { Suggested to report } \\
\text { anosmia or ageusia as } \\
\text { important } \\
\text { symptoms of the } \\
\text { COVID-19 infection. }\end{array}$ \\
\hline $\begin{array}{l}\text { Mao L et } \\
a l, 2020^{16}\end{array}$ & 214 & Observational & $\begin{array}{l}\text { COVID-19 } \\
\text { positive }\end{array}$ & NA & $\begin{array}{l}\text { Neurological sign }(78 / 214) \\
\text { Headache }(28 / 214), \\
\text { Dizziness }(36 / 214), \\
\text { Impaired } \\
\text { consciousness(16/78), } \\
\text { ataxia, acute cerebrovascular } \\
\text { disease (6/78) and Epilepsy } \\
\text { Peripheral nervous system } \\
\text { (PNS) symptoms } \\
\text { skeletal muscular symptoms } \\
\text { (23/78) } \\
\text { Hypogeusia }(12 / 214) \\
\text { Hyposmia (11/214) }\end{array}$ & $\begin{array}{l}\text { Head CT, Swab } \\
\text { test }\end{array}$ & CNS \& PNS & $\begin{array}{l}\text { Non-severe severe } \\
\text { COVID-19 patients } \\
\text { reported } \\
\text { neurologic symptoms } \\
\text { manifested as acute } \\
\text { cerebrovascular } \\
\text { diseases, consciousness } \\
\text { impairment and skeletal } \\
\text { muscle symptoms. }\end{array}$ \\
\hline Wang $\mathrm{D}$ et & 138 & Observational & COVID-19 & Oseltamivir & Headache (9), & RT-PCR & CNS & Identified common sign \\
\hline
\end{tabular}

Page 12/24 


\begin{tabular}{|c|c|c|c|c|c|c|c|c|}
\hline$a l, 2020^{17}$ & & & positive & $\begin{array}{l}\text { Methylprednisolone } \\
\text { Azithromycin } \\
\text { Moxifloxacin, Ceftriaxone, }\end{array}$ & $\begin{array}{l}\text { Dizziness (13), } \\
\text { Dyspnea (5) }\end{array}$ & & & $\begin{array}{l}\text { and symptoms at } \\
\text { COVID-19 onset were } \\
\text { fever, dry cough, } \\
\text { myalgia, fatigue, } \\
\text { dyspnea, and anorexia. }\end{array}$ \\
\hline $\begin{array}{l}\text { Wang Z } \\
\text { et al, } \\
2020^{18}\end{array}$ & 69 & Observational & $\begin{array}{l}\text { COVID-19 } \\
\text { positive }\end{array}$ & $\begin{array}{l}\text { oxygen support, } \\
\text { Corticosteroids, } \\
\text { Moxifoxacin }\end{array}$ & $\begin{array}{l}\text { Dyspnea }(15 / 69), \\
\text { Dysgeusia }(5 / 69), \\
\text { Ageusia }(1 / 69), \\
\text { Hyposmia }(3 / 69), \\
\text { Dysgeusia and hyposmia } \\
(2 / 69), \\
\text { Dysgeusia and anosmia } \\
(2 / 69), \\
\text { Ageusia and hyposmia } \\
(2 / 69), \\
\text { Ageusia and anosmia }(5 / 69)\end{array}$ & $\begin{array}{l}\text { nasopharyngeal } \\
\text { swab test (RT- } \\
\text { PCR }\end{array}$ & CNS \& PNS & $\begin{array}{l}\text { Older patients or those } \\
\text { with underlying } \\
\text { comorbidities are at } \\
\text { higher risk of death. }\end{array}$ \\
\hline
\end{tabular}

Table: 2; Published case reports of neurological manifestations in COVID-19 positive patients 


\begin{tabular}{|c|c|c|c|c|c|c|c|c|}
\hline $\begin{array}{l}\text { Author, } \\
\text { year }\end{array}$ & $\begin{array}{l}\text { Sample } \\
\text { Size } \\
\text { (SS) }\end{array}$ & $\begin{array}{l}\text { Type of Study } \\
\text { (ST) }\end{array}$ & $\begin{array}{l}\text { Patient } \\
\text { Population }\end{array}$ & Treatment & $\begin{array}{l}\text { Neurological condition } \\
\text { (NC) }\end{array}$ & $\begin{array}{l}\text { 2019-nCoV } \\
\text { Presence and } \\
\text { diagnosis }\end{array}$ & $\begin{array}{l}\text { Type of NS } \\
\text { involvement } \\
\text { (CNS/PNS) } \\
\text { (NSI) }\end{array}$ & Remarks \\
\hline $\begin{array}{l}\text { Duong L } \\
\text { et al, } \\
2020^{19}\end{array}$ & 01 & case report & COVID-19 & $\begin{array}{l}\text { (Ceftriaxone and Vancomycin, } \\
\text { Acyclovir, HCQ }\end{array}$ & Meningoencephalitis & PCR (CSF- NA) & CNS & $\begin{array}{l}\text { They have observed } \\
\text { a COVID-19 } \\
\text { infection } \\
\text { presenting as an } \\
\text { isolated } \\
\text { meningoencephalitis } \\
\text { without respiratory } \\
\text { involvement. }\end{array}$ \\
\hline $\begin{array}{l}\text { Karimi N } \\
\text { et al, } \\
2020^{08}\end{array}$ & 01 & Case report & $\begin{array}{l}\text { COVID-19 } \\
\text { positive }\end{array}$ & $\begin{array}{l}\text { chloroquine and } \\
\text { Lopinavir-ritonavir }\end{array}$ & GTC convulsion & Brain MRI & CNS & $\begin{array}{l}\text { Association between } \\
\text { frequent seizures } \\
\text { and COVID-19 } \\
\text { may be due to } \\
\text { encephalitis } \\
\text { and the invasion of } \\
\text { the virus to the } \\
\text { brain or toxic effect } \\
\text { of } \\
\text { inflammatory } \\
\text { cytokines. }\end{array}$ \\
\hline $\begin{array}{l}\text { Moriguchi } \\
\text { T, et al, } \\
2020^{22}\end{array}$ & 01 & Case Report & & Laninamivir and antipyretic & Meningitis/encephalitis & & CNS & $\begin{array}{l}\text { specific SARS-CoV-2 } \\
\text { RNA was not } \\
\text { detected in the } \\
\text { nasopharyngeal } \\
\text { swab, it was } \\
\text { detected in CSF }\end{array}$ \\
\hline $\begin{array}{l}\text { Paniz- } \\
\text { Mondolfi } \\
\text { A et al, } \\
2020^{23}\end{array}$ & 01 & Case report & $\begin{array}{l}\text { COVID-19 } \\
\text { positive }\end{array}$ & HCQ \& Enoxaparin & $\begin{array}{l}\text { Confusion } \\
\text { Agitation and } \\
\text { combative. }\end{array}$ & $\begin{array}{l}\text { nasopharyngeal } \\
\text { swab test (RT- } \\
\text { PCR positive) }\end{array}$ & CNS & $\begin{array}{l}\text { Transmission } \\
\text { electron microscopy } \\
\text { of sections obtained } \\
\text { at post-mortem } \\
\text { examination } \\
\text { revealed the } \\
\text { presence of } 80 \text { to } \\
110 \mathrm{~nm} \text { viral } \\
\text { particles in frontal } \\
\text { lobe brain sections }\end{array}$ \\
\hline $\begin{array}{l}\text { Scheidl et } \\
\text { al, } 2020^{24}\end{array}$ & 01 & Case report & $\begin{array}{l}\text { COVID-19 } \\
\text { positive }\end{array}$ & NA & $\begin{array}{l}\text { Guillain Barre } \\
\text { syndrome }\end{array}$ & $\begin{array}{l}\text { RT-PCR } \\
\text { positive }\end{array}$ & PNS & $\begin{array}{l}\text { Our case draws } \\
\text { attention to the } \\
\text { occurrence of GBS } \\
\text { also in patients with } \\
\text { COVID-19 (corona } \\
\text { virus disease 2019), } \\
\text { who did not } \\
\text { experience } \\
\text { respiratory or } \\
\text { general symptoms. }\end{array}$ \\
\hline $\begin{array}{l}\text { Sedaghat } \\
\text { Z et al, } \\
2020^{25}\end{array}$ & 01 & Case report & $\begin{array}{l}\text { COVID-19 } \\
\text { positive }\end{array}$ & $\begin{array}{l}\text { HCQ, Lopinavir/ Ritonavir } \\
\text { (LPV/RTV) Azithromycin. }\end{array}$ & $\begin{array}{l}\text { Guillain Barre } \\
\text { syndrome }\end{array}$ & $\begin{array}{l}\text { RT-PCR } \\
\text { positive }\end{array}$ & PNS & $\begin{array}{l}\text { Suggested the } \\
\text { treatment with IVIG } \\
\text { or plasmapheresis } \\
\text { should be initiated } \\
\text { along with antiviral } \\
\text { treatment. }\end{array}$ \\
\hline $\begin{array}{l}\text { Somani S } \\
\text { et al, } \\
2020^{26}\end{array}$ & 01 & Case report & & $\begin{array}{l}\text { levetiracetam, lacosamide, } \\
\text { Phenytoin, Midazolam }\end{array}$ & $\begin{array}{l}\text { Dyspnea }(1 / 2) \\
\text { Myalgias }(1 / 2 \\
\text { Myoclonic status } \\
\text { Epilepticus with coma } \\
\text { (MSE) }(1 / 2)\end{array}$ & $\begin{array}{l}\text { RT-PCR } \\
\text { positive }\end{array}$ & CNS \& PNS & $\begin{array}{l}\text { Asymptomatic } \\
\text { COVID-19. Altered } \\
\text { mental status in } \\
\text { patients with } \\
\text { COVID-19 }\end{array}$ \\
\hline
\end{tabular}




\begin{tabular}{|c|c|c|c|c|c|c|c|c|}
\hline $\begin{array}{l}\text { Toscano } \\
\text { G, et al } \\
2020^{27}\end{array}$ & 05 & Correspondence & $\begin{array}{l}\text { COVID-19 } \\
\text { positive } \\
(4 / 5)\end{array}$ & Intravenousimmuneglobulin(IVIG) & $\begin{array}{l}\text { Guillain-Barré } \\
\text { syndrome }\end{array}$ & $\begin{array}{l}\text { RT-PCR } \\
\text { positive }\end{array}$ & PNS & $\begin{array}{l}\text { First symptoms of } \\
\text { Guillain- } \\
\text { Barré syndrome is } \\
\text { similar to the } \\
\text { interval } \\
\text { seen with Guillain- } \\
\text { Barré syndrome that } \\
\text { occurs } \\
\text { during or after other } \\
\text { infections }\end{array}$ \\
\hline $\begin{array}{l}\text { Virani A } \\
\text { et al, } \\
2020^{28}\end{array}$ & 01 & Case report & $\begin{array}{l}\text { COVID-19 } \\
\text { positive }\end{array}$ & $\begin{array}{l}\text { Intravenousimmuneglobulin(IVIG) } \\
\text { HCQ }\end{array}$ & $\begin{array}{l}\text { Guillain-Barré } \\
\text { syndrome }\end{array}$ & $\begin{array}{l}\text { RT-PCR } \\
\text { positive }\end{array}$ & PNS & $\begin{array}{l}\text { Author cognizant of } \\
\text { the neurological } \\
\text { presentation of GBS } \\
\text { that is likely } \\
\text { associated with } \\
\text { SARS-CoV-2 } \\
\text { infection. }\end{array}$ \\
\hline $\begin{array}{l}\text { Zhao H et } \\
\text { al, } 2020^{29}\end{array}$ & 01 & Case Report & $\begin{array}{l}\text { COVID-19 } \\
\text { positive }\end{array}$ & Arbidol, Lopinavir, Ritonavir & $\begin{array}{l}\text { Guillain-Barré } \\
\text { syndrome. }\end{array}$ & $\begin{array}{l}\text { RT-PCR } \\
\text { positive }\end{array}$ & PNS & $\begin{array}{l}\text { Study showed a } \\
\text { possible causal } \\
\text { association between } \\
\text { Guillain-Barré } \\
\text { syndrome and } \\
\text { SARS-CoV-2 } \\
\text { infection }\end{array}$ \\
\hline
\end{tabular}

NS: Nervous system; HCQ: Hydroxy chloroquine; 


\begin{tabular}{|c|c|c|c|c|c|c|c|}
\hline $\begin{array}{l}\text { Sample } \\
\text { Size }\end{array}$ & $\begin{array}{l}\text { Type of } \\
\text { Study }\end{array}$ & $\begin{array}{l}\text { Patient } \\
\text { Population }\end{array}$ & Treatment & $\begin{array}{l}\text { Neurological } \\
\text { condition }\end{array}$ & $\begin{array}{l}2019- \\
\mathrm{nCoV} \\
\text { Presence } \\
\text { and } \\
\text { diagnosis }\end{array}$ & $\begin{array}{l}\text { Type of NS } \\
\text { involvement } \\
\text { (CNS/PNS) } \\
\text { (NSI) }\end{array}$ & Remarks \\
\hline 01 & Case Report & SARS-CoV & $\begin{array}{l}\text { Broadspectrum } \\
\text { antibiotics and } \\
\text { inhalation of } \\
\text { Ribavirin }\end{array}$ & $\begin{array}{l}\text { Myalgia } \\
\text { (Weakness and } \\
\text { numbness in } \\
\text { both legs) }\end{array}$ & $\begin{array}{l}\text { chest } \mathrm{x}- \\
\text { ray } \\
\text { (CXR), } \\
\text { PCR }\end{array}$ & PNS & $\begin{array}{l}\text { Systemic inflammatory response syndrome, has } \\
\text { been proposed to play a role in the nerve } \\
\text { damage. }\end{array}$ \\
\hline 01 & Case Report & SARS-CoV & $\begin{array}{l}\text { Ribavirin } \\
\text { Propofol Phenytoin }\end{array}$ & Seizure & $\begin{array}{l}\text { RT PCR, } \\
\text { CSF }\end{array}$ & CNS & $\begin{array}{l}\text { First reported the entry of SARS-CoV into the } \\
\text { CSF. }\end{array}$ \\
\hline 01 & Case Report & SARS-CoV & $\begin{array}{l}\text { Ribavirin, } \\
\text { Prednisolone }\end{array}$ & Anosmia & RT-PCR & PNS & $\begin{array}{l}\text { Anosmia persisted } \\
\text { during more than two years of follow-up. }\end{array}$ \\
\hline 01 & Case Report & SARS-CoV & $\begin{array}{l}\text { Ribavirin } \\
\text { hydrocortisone }\end{array}$ & $\begin{array}{l}\text { Myalgia } \\
\text { GTC }\end{array}$ & $\begin{array}{l}\text { RT-PCR } \\
\text { CSF-P }\end{array}$ & CNS \& PNS & $\begin{array}{l}\text { Generalized convulsion with a positive RT-PCR } \\
\text { for SARS-CoV in the CSF suggests possible } \\
\text { infection of the central nervous system by } \\
\text { SARS-CoV. }\end{array}$ \\
\hline 05 & Observational & SARS-CoV & $\begin{array}{l}\text { Immunoglobulin } \\
\text { (IVIg), } \\
\text { Methylprednisolone, } \\
\text { Ribavarin, } \\
\text { Convalescent } \\
\text { serum, LMWH }\end{array}$ & $\begin{array}{l}\text { Loss of } \\
\text { consciousness } \\
(1 / 5) \\
\text { Infarction } \\
(5 / 5)\end{array}$ & & CNS & $\begin{array}{l}\text { Out of } 206,05 \text { patients experience neurological } \\
\text { manifestations. All five have experience d } \\
\text { cerebral infarction. }\end{array}$ \\
\hline
\end{tabular}

Middle East respiratory syndrome corona virus (MERS-CoV)

\begin{tabular}{|c|c|c|c|c|c|c|c|}
\hline $\begin{array}{l}\text { Sample } \\
\text { Size }\end{array}$ & $\begin{array}{l}\text { Type of } \\
\text { Study }\end{array}$ & $\begin{array}{l}\text { Patient } \\
\text { Population }\end{array}$ & Treatment & $\begin{array}{l}\text { Neurological } \\
\text { condition }\end{array}$ & $\begin{array}{l}\text { 2019- } \\
\text { nCoV } \\
\text { Presence } \\
\text { and } \\
\text { diagnosis }\end{array}$ & $\begin{array}{l}\text { Type of NS } \\
\text { involvement } \\
\text { (CNS/PNS) } \\
\text { (NSI) }\end{array}$ & Remarks \\
\hline 02 & Observational & $\begin{array}{l}\text { MERS- } \\
\text { CoV } \\
\text { positive }\end{array}$ & $\begin{array}{l}\text { Intravenous } \\
\text { hydration, Tazocin, } \\
\text { Azithromycin }\end{array}$ & $\begin{array}{l}\text { Headache, } \\
\text { Nausea, and } \\
\text { vomiting. } \\
\text { Myalgia, } \\
\text { Dizziness } \\
\text { Intracerebral } \\
\text { hemorrhage }\end{array}$ & RT-PCR & CNS \& PNS & $\begin{array}{l}\text { CT showed right frontal lobe intracerebral } \\
\text { hemorrhage with massive brain edema and midline } \\
\text { shift of } 02 \text { patients among } 120 \text { patinets. }\end{array}$ \\
\hline 03 & Observational & $\begin{array}{l}\text { MERS- } \\
\text { CoV } \\
\text { positive }\end{array}$ & NA & $\begin{array}{l}\text { Ataxia }(1 / 3) \text {, } \\
\text { Vomiting } \\
(2 / 3), \\
\text { Confusion }(2 / 3) \\
\text { Dysmetria } \\
(1 / 3) \\
\text { Dyspnea and } \\
\text { hypoxia }(1 / 3) \\
\text { Encephalitis } \\
(1 / 3)\end{array}$ & $\begin{array}{l}\text { RT-PCR } \\
\text { and CSF }\end{array}$ & CNS \& PNS & $\begin{array}{l}\text { Brain MRI revealed striking changes char- acterized } \\
\text { by widespread, bilateral hyperintense lesions on T2- } \\
\text { weighted imaging within the white matter and } \\
\text { subcortical areas of the frontal, temporal, and } \\
\text { parietal lobes, the basal ganglia, and corpus } \\
\text { callosum. }\end{array}$ \\
\hline 01 & Case report & $\begin{array}{l}\text { MERS- } \\
\text { CoV }\end{array}$ & $\begin{array}{l}\text { Peginterferon } \\
\text { Alpha-2a, Ribavirin, }\end{array}$ & $\begin{array}{l}\text { Intracerebral } \\
\text { hemorrhage }\end{array}$ & RT-PCR & CNS & Neurological symptoms asociated with MERS-COV \\
\hline
\end{tabular}




\begin{tabular}{|c|c|c|c|c|c|c|c|}
\hline & & positive & $\begin{array}{l}\text { and } \\
\text { Methylprednisolone } \\
\text { (i.v.) }\end{array}$ & $\begin{array}{l}\text { Shortness of } \\
\text { breath }\end{array}$ & & & \\
\hline $04 / 23$ & Observational & $\begin{array}{l}\text { MERS- } \\
\mathrm{CoV} \\
\text { positive }\end{array}$ & $\begin{array}{l}\text { Interferon alpha-2a, } \\
\text { Ribavirin, and } \\
\text { Lopinavir/ } \\
\text { Ritonavir }\end{array}$ & $\begin{array}{l}\text { Dyspnea }(2 / 4) \\
\text { Myalgia or } \\
\text { arthralgia } \\
(2 / 4) \\
\text { Guillain-Barré } \\
\text { syndrome } \\
(2 / 4) \\
\text { Acute sensory } \\
\text { neuropathy } \\
(3 / 4) \\
\text { Headache } \\
(2 / 23) \\
\text { Confusion } \\
(5 / 23) \\
\text { Seizure (0/23) } \\
\text { Nausea and } \\
\text { vomiting } \\
\text { (18/23) }\end{array}$ & RT-PCR & CNS \& PNS & $\begin{array}{l}\text { GBS, ICU-acquired weakness, or acute sensory } \\
\text { neuropathy that resulted from a toxin or infection }\end{array}$ \\
\hline 70 & Observational & $\begin{array}{l}\text { MERS- } \\
\text { CoV } \\
\text { positive }\end{array}$ & NA & $\begin{array}{l}\text { Shortness of } \\
\text { breath }(42 / 70) \\
\text { Fatigue } \\
(29 / 70) \\
\text { Myalgia or } \\
\text { arthralgia } \\
(14 / 70) \\
\text { Vomitting } \\
(21 / 70) \\
\text { Headache } \\
(9 / 70) \\
\text { Confusion } \\
(18 / 70)\end{array}$ & RT-PCR & & $\begin{array}{l}\text { MERS-CoV can cause severe infection in the age } \\
\geq 65 \text { years with more requirement of intensive care } \\
\text { and a high mortality. }\end{array}$ \\
\hline
\end{tabular}

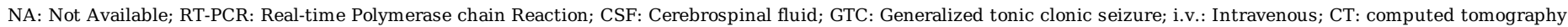

\section{Figures}


Records identified through database searching $(n=2615)$

Records screened (title and abstract)

$$
(\mathrm{n}=1651)
$$
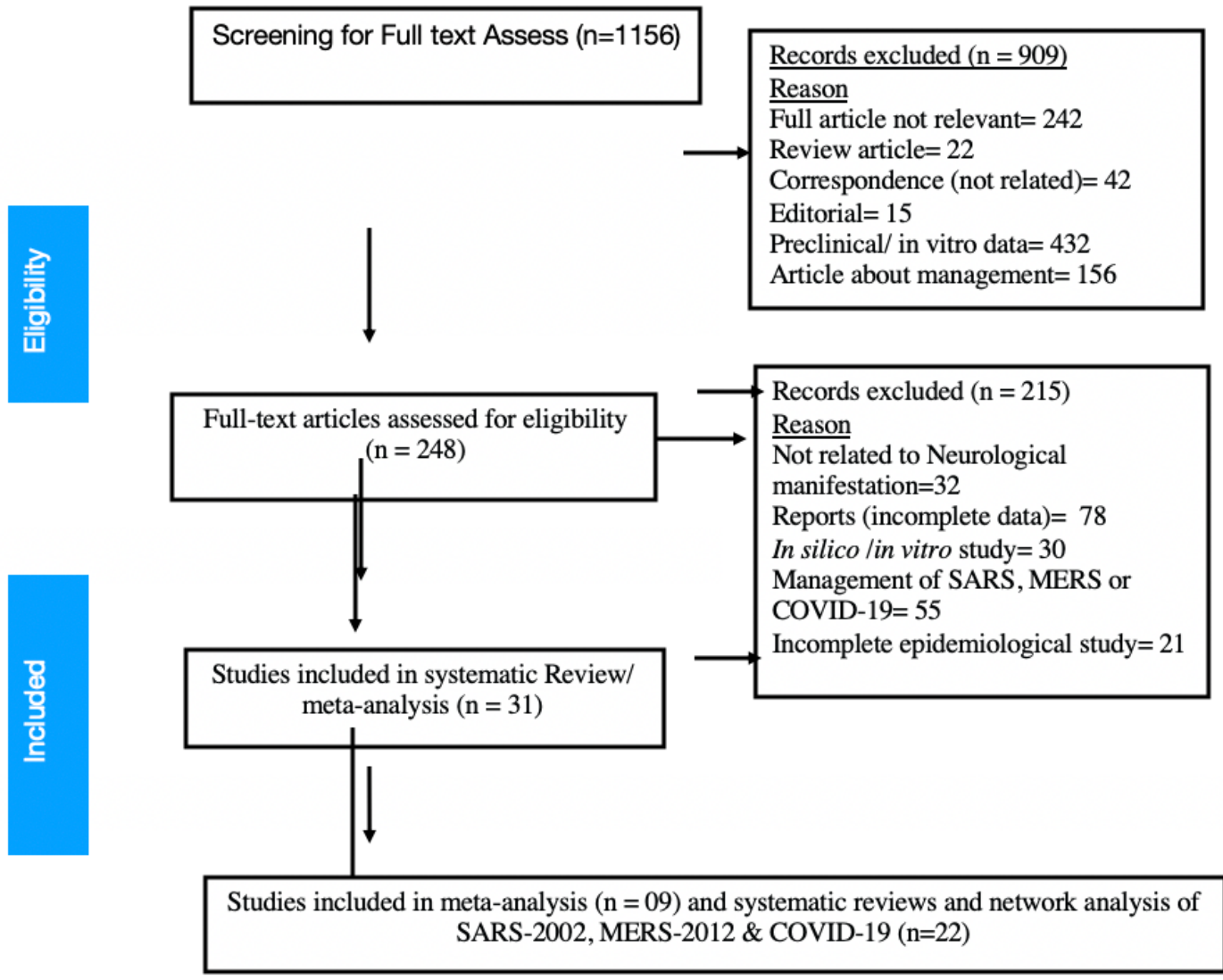

Duplicate studies removed

$(n=964)$

Records excluded $(n=495)$

Reason

Irrelevant title \& abstract $=281$

Conference abstracts- not related $=179$

Review article $=24$

Mini review $=05$

Pooled analysis $=03$

Un-related retrospective data $=03$

Figure 1

PRISMA chart showing study section criteria and process 
CNS/PNS

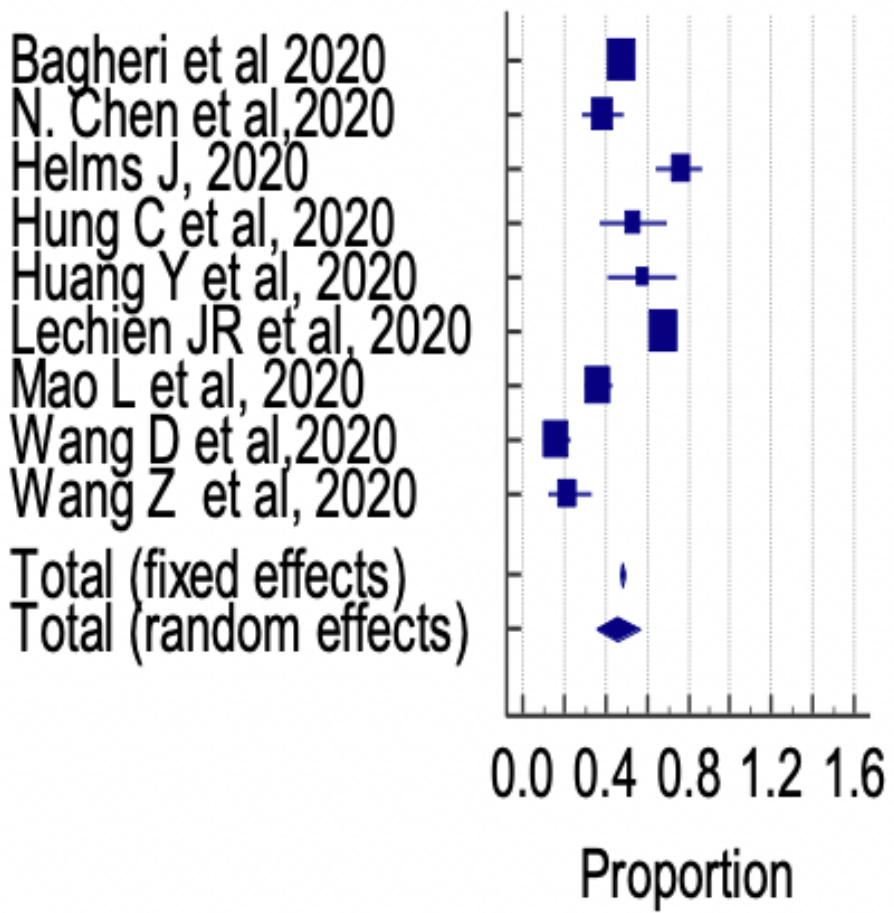

CNS/PNS

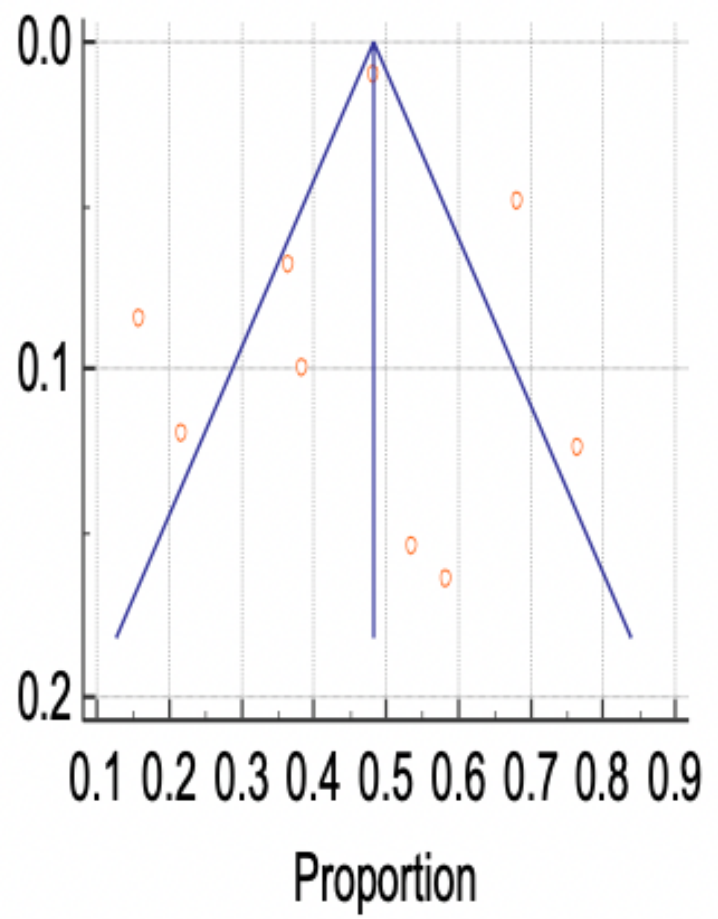

Figure 2

a: Forest plot showing pooled prevalence of CNS-PNS combined among patients with COVID-19 patients. b: Funnel plot showing publication bias among studies evaluating neurological complications of COVID-19.

CNS
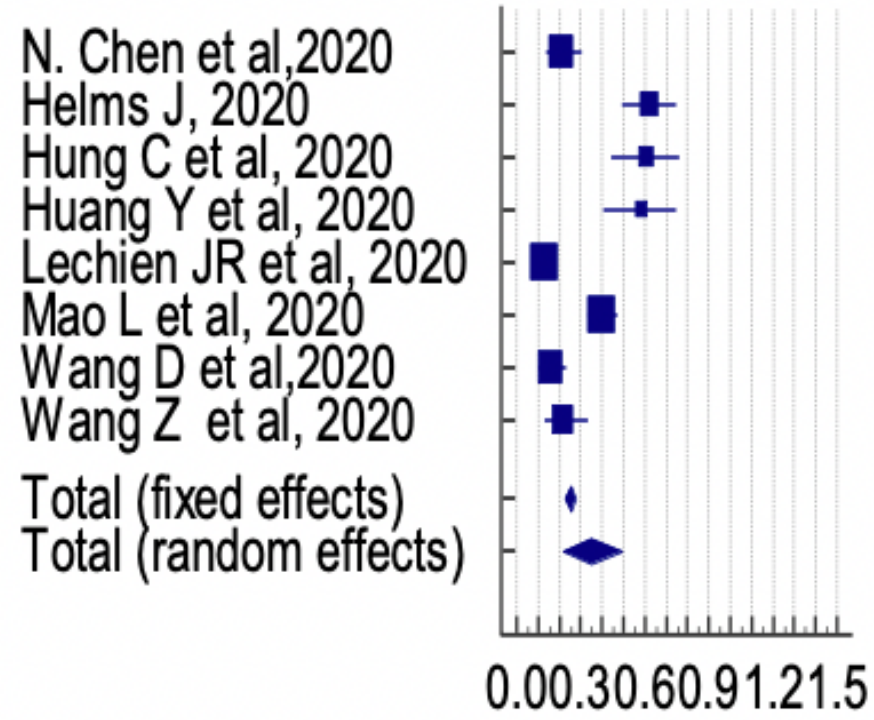

Proportion
CNS

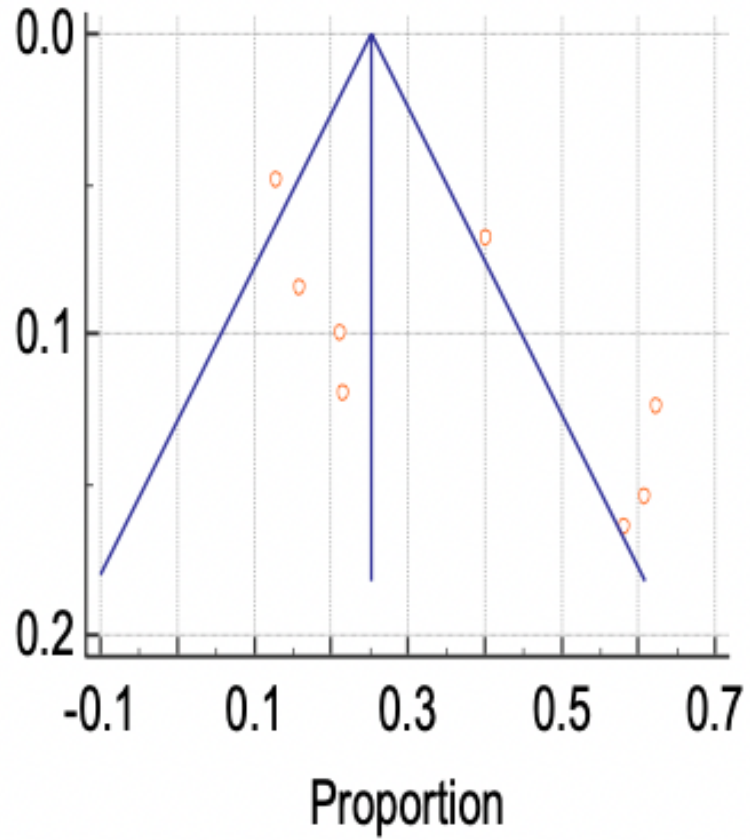

Figure 3 
PNS

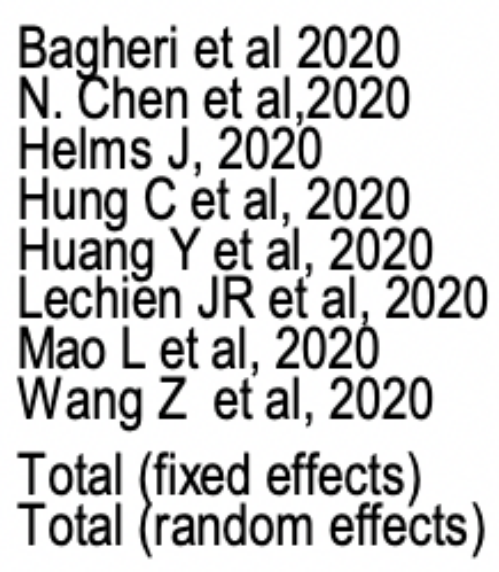

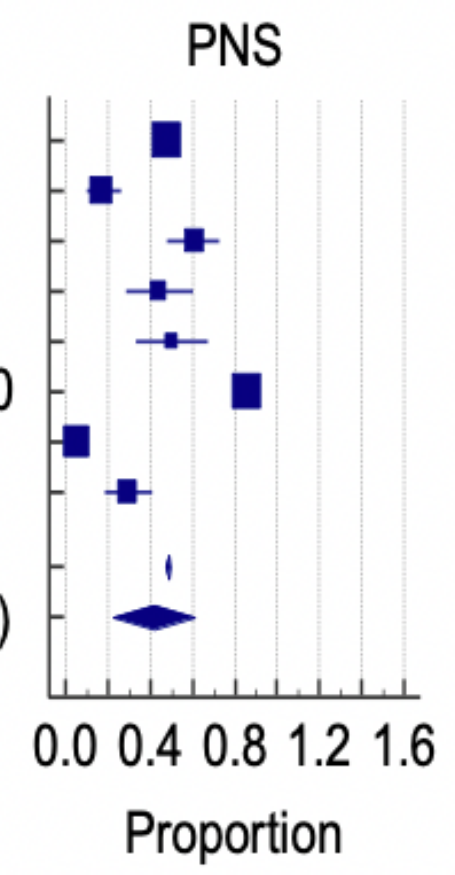

Figure 4

a: Forest plot showing pooled prevalence of PNS complications among patients with COVID-19. b: Funnel plot showing publication bias among studies evaluating neurological complications of COVID-19.
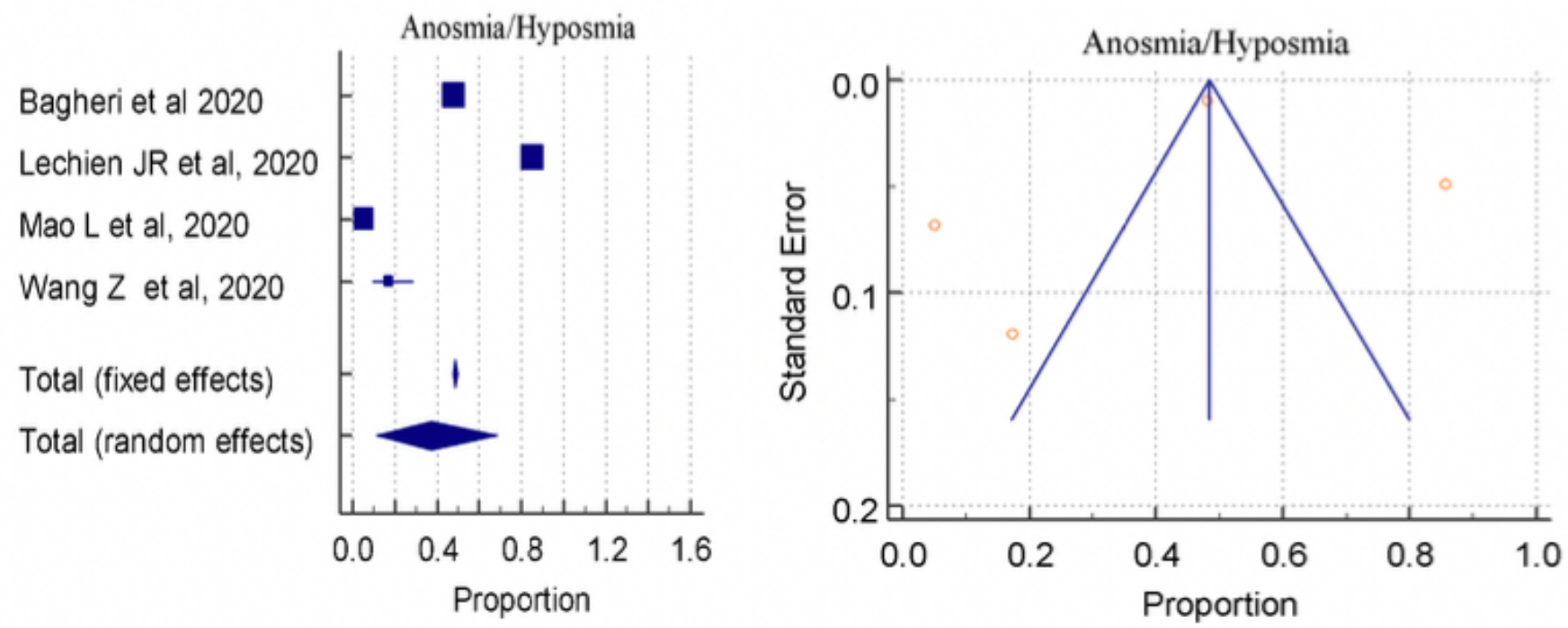

Figure 5

a: Forest plot showing pooled prevalence of ANSOMIA/HYPOSMIA complications among patients with COVID-19. $b$ : Funnel plot showing publication bias among studies evaluating neurological complications of COVID-19. 

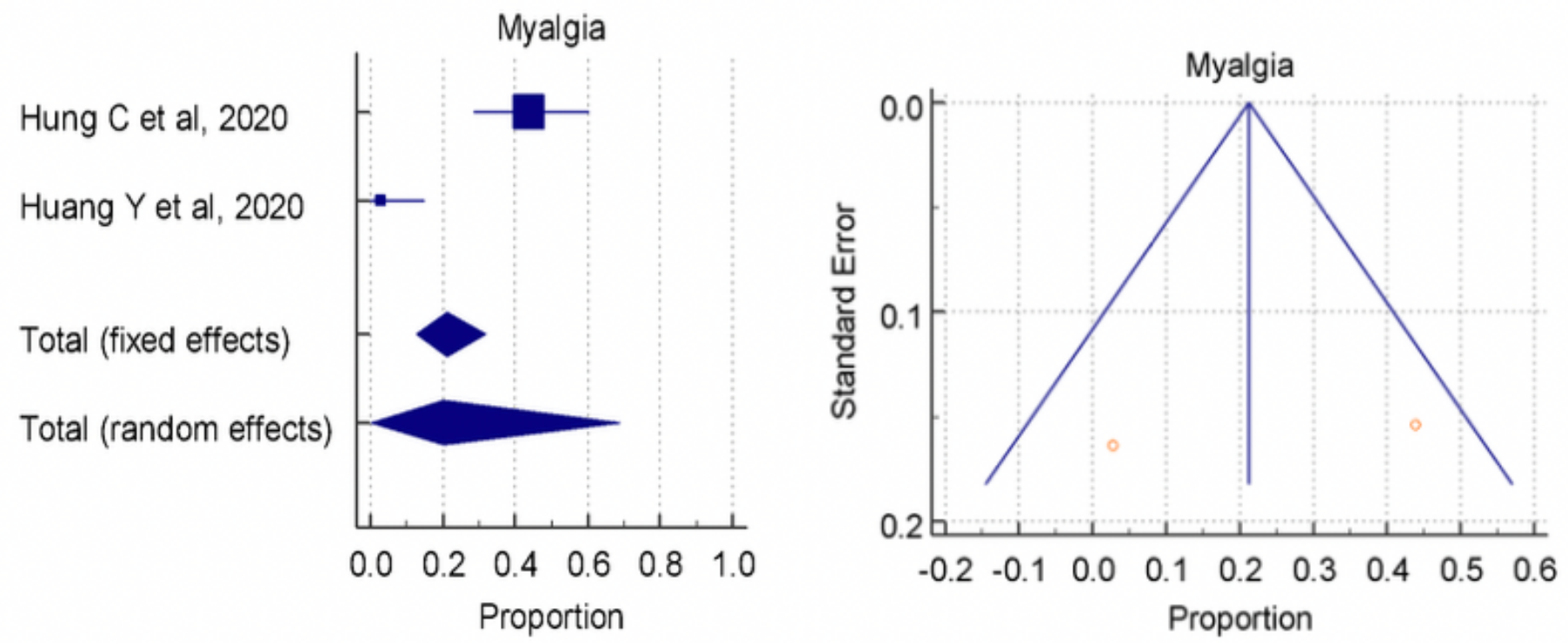

Figure 6

a: Forest plot showing pooled prevalence of Myalgia among patients with COVID-19. Incidence of Myalgia symptoms. b: Funnel plot showing publication bias among studies evaluating neurological complications of COVID-19.

Fatigue

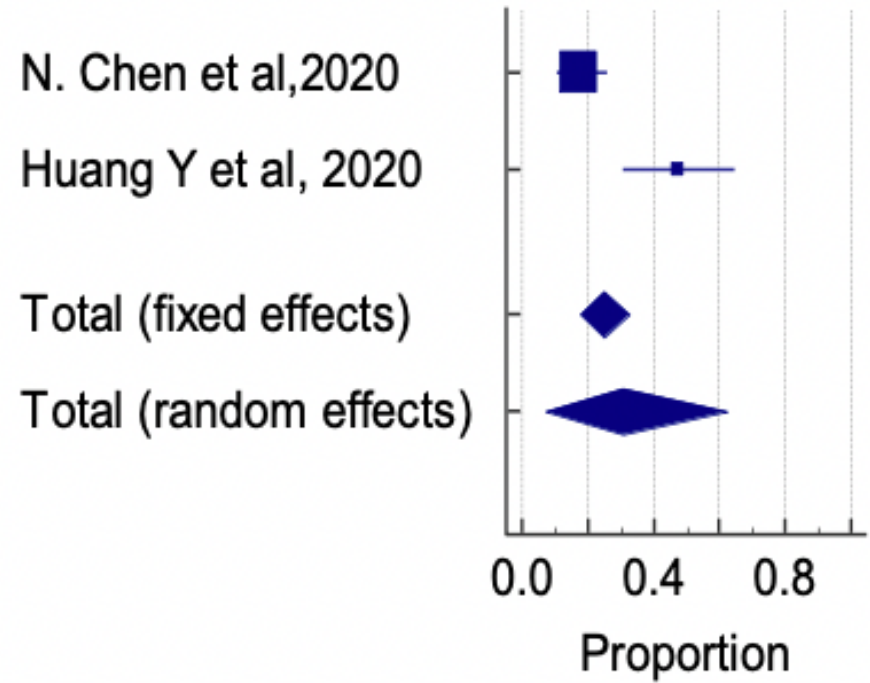

Fatigue

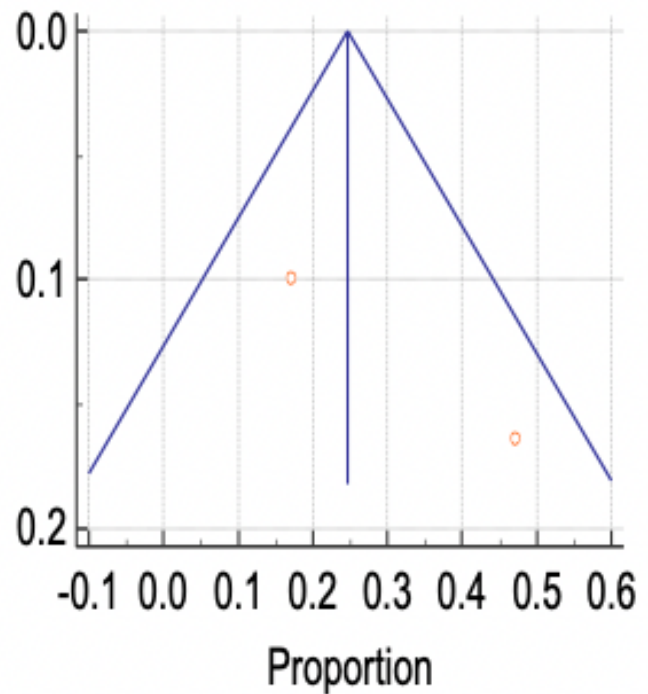

Figure 7

a: Forest plot showing pooled prevalence of Fatigue among patients with COVID-19. b: Funnel plot showing publication bias among studies evaluating neurological complications of COVID-19. 

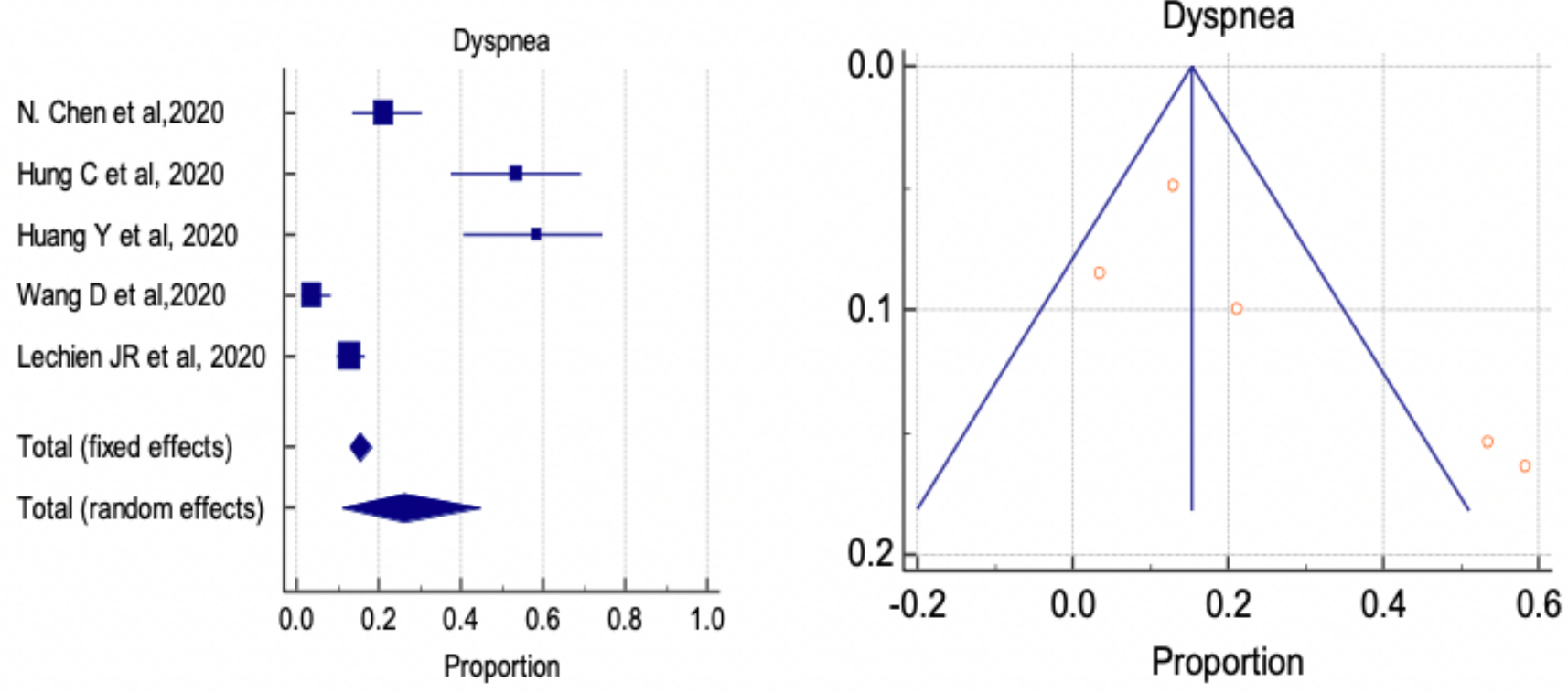

Figure 8

a: Forest plot showing pooled prevalence of Dyspnea among patients with COVID-19. b: Funnel plot showing publication bias among studies evaluating neurological complications of COVID-19.
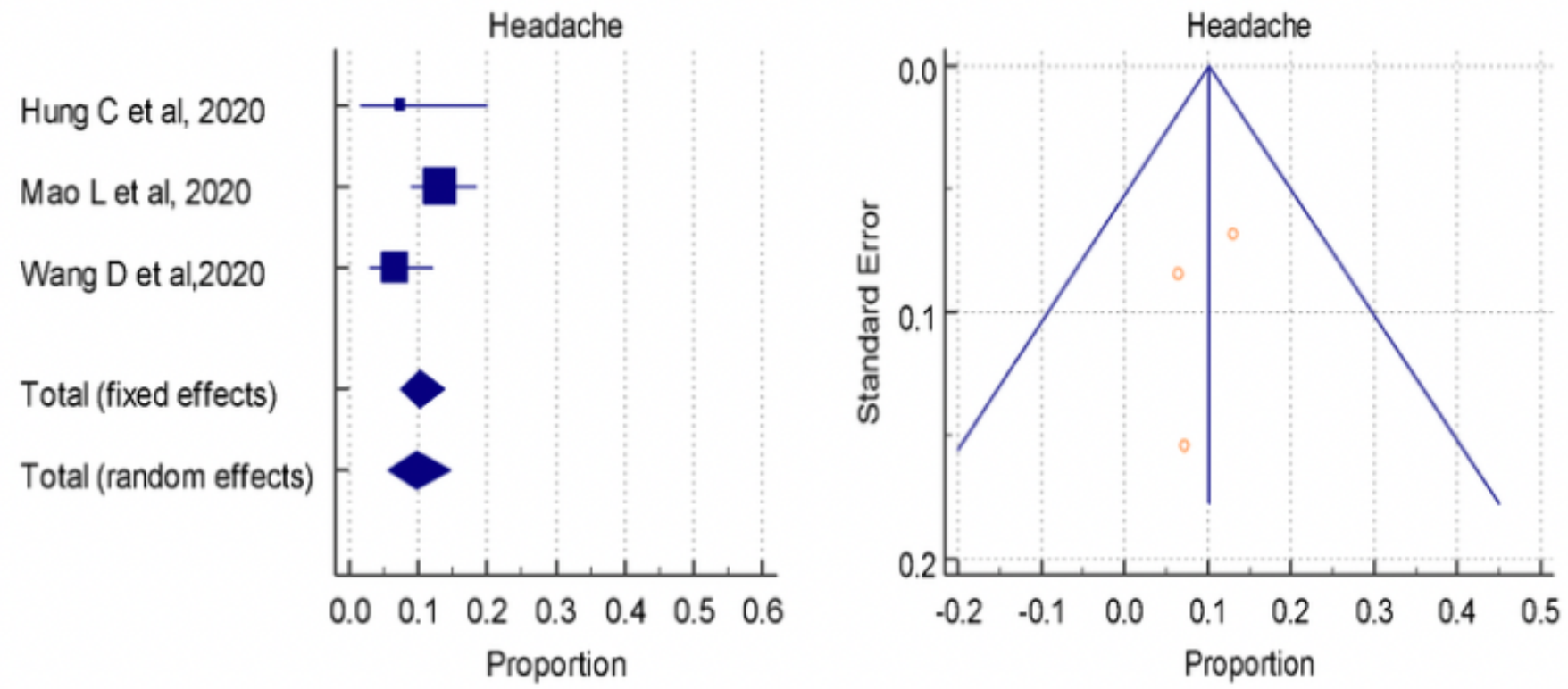

Figure 9

a: Forest plot showing pooled prevalence of Headache among patients with COVID-19. b: Funnel plot showing publication bias among studies evaluating neurological complications of COVID-19. 

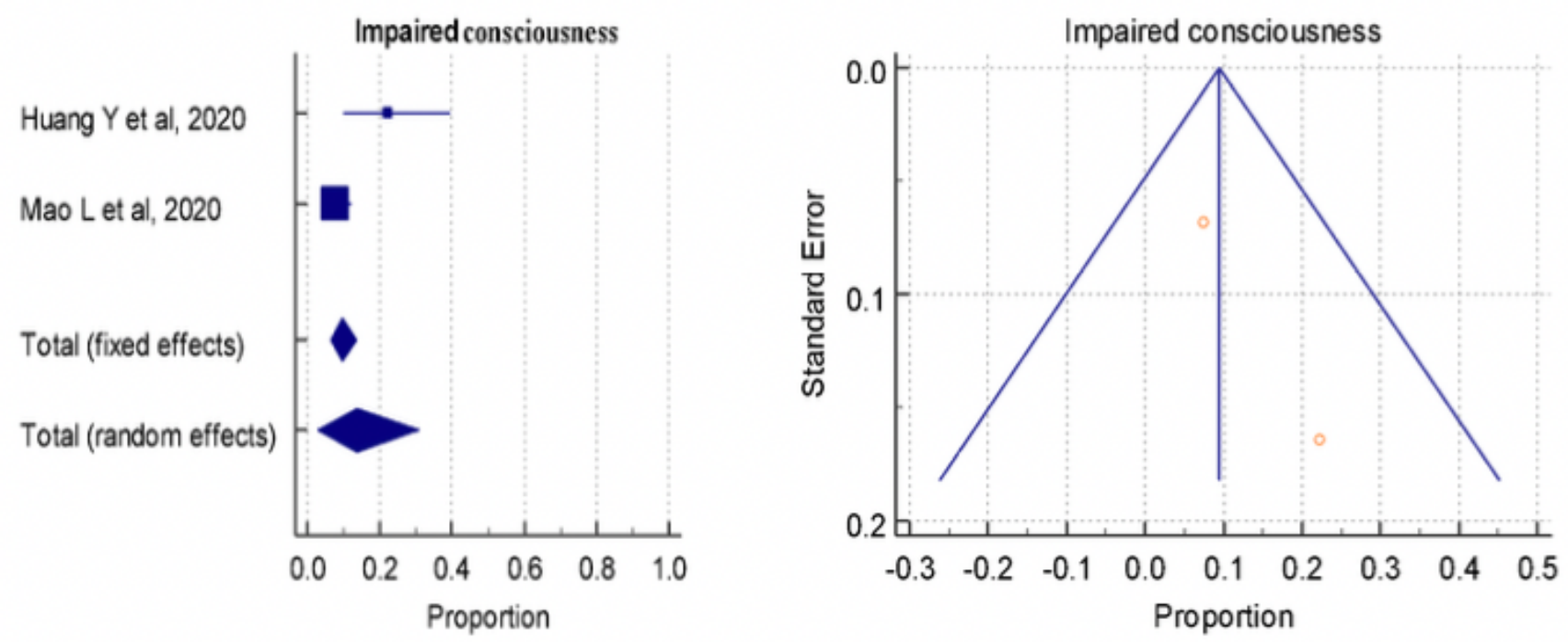

Figure 10

a: Forest plot showing pooled prevalence/incidence of Impaired Consciousness among patients with COVID-19. b: Funnel plot showing publication bias among studies evaluating neurological complications of COVID-19.

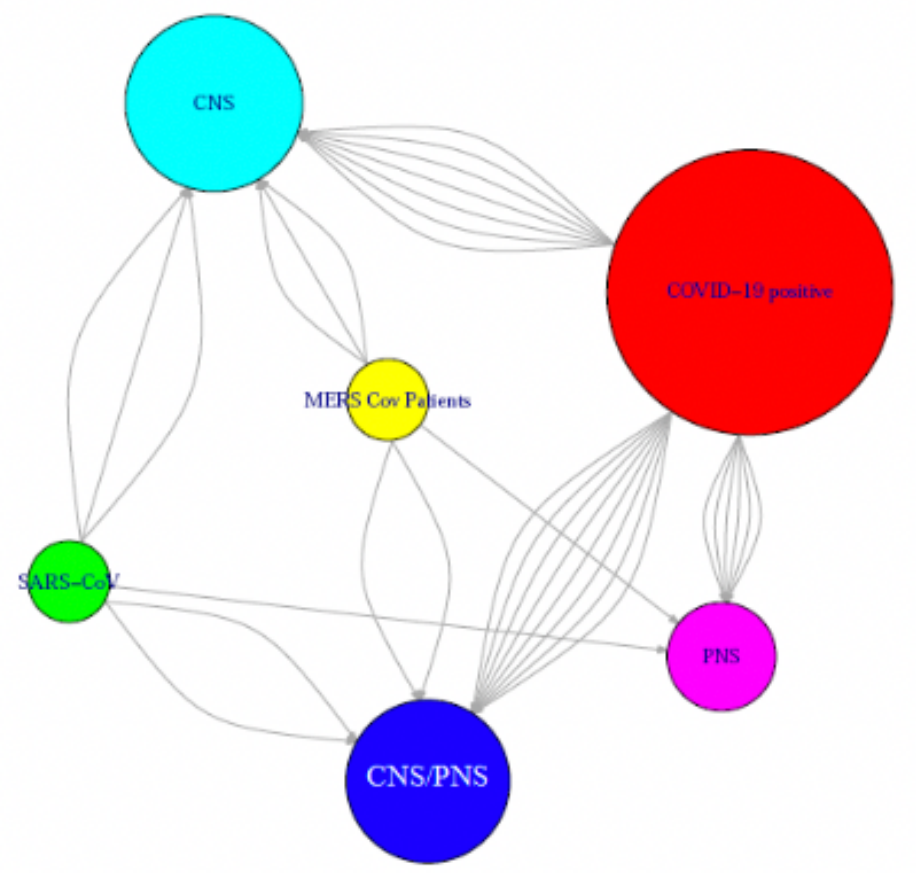

Figure 11

Overall Network analysis which showed the relationship with three main pandemics i.e. SARS-2002, MERS-2012 and COVID-19 with the CNS, PNS or combined manifestations. Note: The size of node define the degree of relation with the 
individual neurological symptoms and increased number of edge give the increased relation with the respective nodes. (Edges showing directed association, Node size depicts degree of nodes)

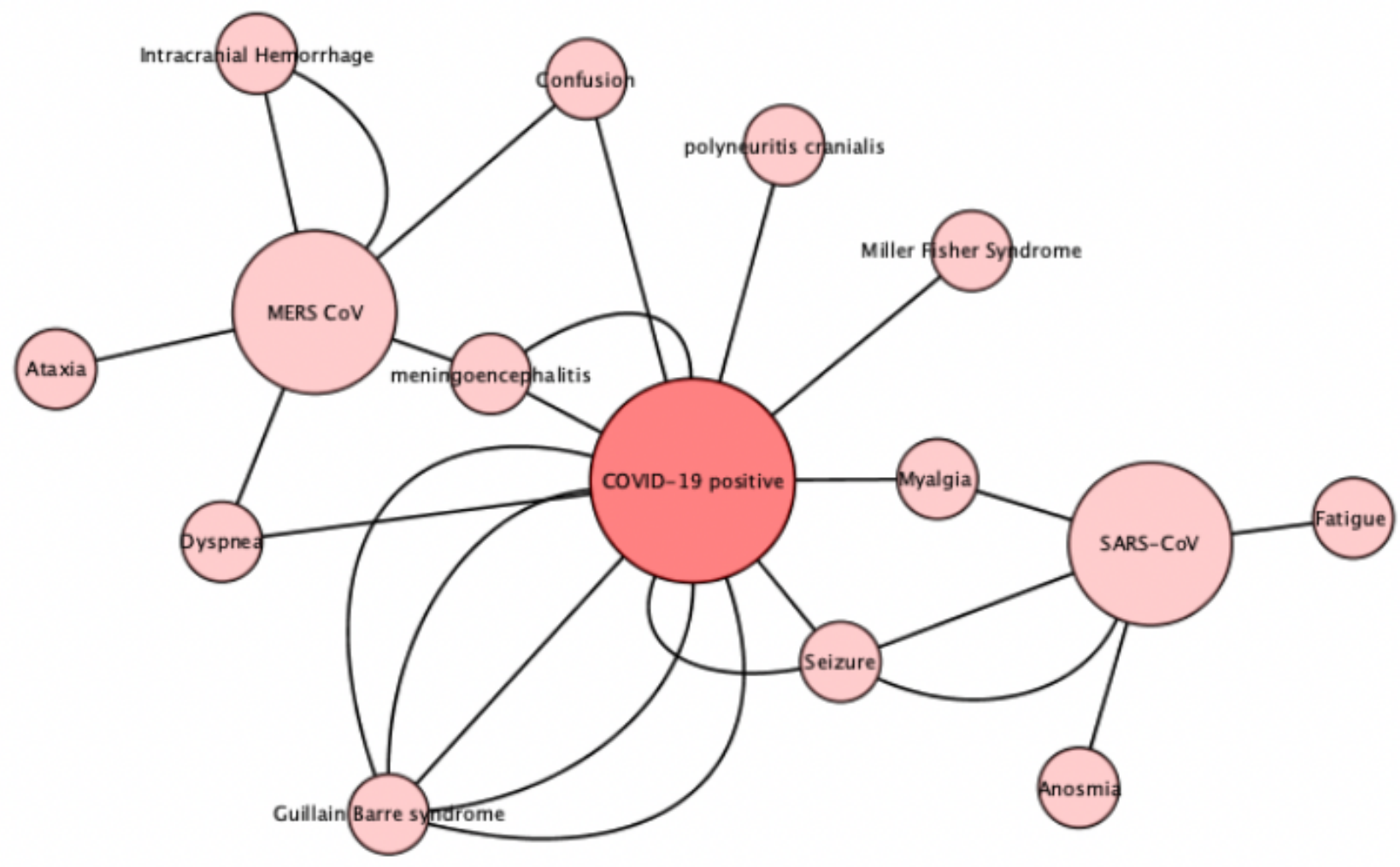

Figure 12

Network analysis showed the impact of neurological manifestation as per described symptoms in case report as well as observational studies. Note: The size of node define the degree of relation with the individual neurological symptoms and increased number of edge give the increased relation with the respective nodes. (Edges showing directed association, Node size depicts degree of nodes) 